\title{
Separação de Poderes e a Independência do Poder Judiciário
}

Joaquim Falcão'

\section{Introdução}

Existem várias maneiras de ler e bem aproveitar este voto do Min. Cezar Peluso, que em muito extrapola os limites da questão em relaçāo à qual o Supremo foi provocado: a constitucionalidade ou não do Conselho Nacional de Justiça. É um voto que faz uma interpretação fundamental dos princípios da separação dos poderes, da independência do judiciário e da imparcialidade jurisdicional, tal como devemos entendê-los a partir da Constituição de 1988. Como tal, é útil a múltiplas áreas de nosso direito público.

Uma primeira maneira é entendê-lo como expressão de um momento decisivo da consolidação de nossa democracia, situando-o em seu devido contexto histórico. Há décadas o Brasil se deparava com um problema de difícil solução: a eficiência do Poder Judiciário. Ou, mais detalhadamente, a lentidão decisória, o controle administrativo e financeiro dos tribunais e o controle ético e disciplinar dos juizes, desembargadores e serventuários. A necessidade de enfrentar este problema cresceu com o advento da Constituição de 1988, e por um motivo simples. No Estado Democrático de Direito, a decisão final para a solução pacífica dos conflitos e divergências sociais cabe ao Poder Judiciário. De fato, nunca na história do Brasil o Poder Judiciário foi tão livre e independente, e nunca teve tanto poder. Mas, por outro lado, nunca a sociedade cobrou tanto eficiência, moralidade

1 Master of Laws (LLM) pela Harvard University. Doutor em Educação pela Universidade de Genebra. Diretor e Professor da Escola de Direito do Rio de Janeiro da Fundação Getulio Vargas (FGV DIREITO RIO) e membro do Conselho Nacional de Justiça. 
e transparência no exercício desse poder. Um Judiciário mais poderoso exige um Judiciário mais ágil, ético e transparente. São, pois, faces da mesma moeda: a consolidação institucional da democracia brasileira.

Há algumas décadas, a sociedade centrou esta busca da eficiência, da moralidade e da transparência na criação de um novo órgão nacional capaz de atingir estes objetivos, exercendo um controle que se mostrava dia após dia mais e mais necessário. Todos se lembram do controle externo da magistratura. Foram escritas e debatidas dezenas de projetos $\epsilon$ anteprojetos que nunca lograram êxito. Mas teve destino distinto e bem-sucedido a Emenda Constitucional 45/04, resultado de uma aliança pouco comum na história legislativa brasileira, um verdadeiro pacto entre os três poderes da República. O Poder Judiciário, representado por seu presidente, o Ministro Nelson Jobim, o Poder Executivo, representado pelo Ministro da Justiça, Marcio Thomaz Bastos, e o Poder Legislativo, representado pelo Senador José Jorge, relator da emenda vitoriosa. O que não foi feito sem muitos e exaustivos debates e, não raramente, sob acirrada oposição. A oposiçāo principal veio de alguns segmentos da própria magistratura, talvez não majoritários, mas certamente poderosos. Esta oposição se revestia de argumentos doutrinários sobre a independência dos juízes e a separação dos poderes. Esses argumentos, este voto os enfrenta.

A segunda maneira então de ler e bem aproveitar este voto é entendê-lo como um debate doutrinário sobre como devemos interpretar em um regime democrático estes seus princípios estruturantes: a imparcialidade dos juízes, a independência jurisdicional e a separação dos poderes. Aqui, o voto do Min. Peluso presta contribuição fundamental à própria epistemologia jurídica. Não faz uma discussão in abstracto. Ao contrário, desenvolve sólida fundamentação, de pés no chāo, onde busca aplicar princípios, normas e valores jurídicos ao caso concreto, à realidade contemporânea do Brasil. Não discute nuvens. Analisa as sombras, a chuva e o sol com que nuvens doutrinárias se transformam e fertilizam ou não a liberdade dos cidadãos. É um aggiornamento conceitual indispensável a todos nós - juízes, políticos, advogados, procuradores, professores e estudantes de direito. Sua clara argumentaçāo tem dois pontos básicos.

Por um lado, afirma que a independência do Poder Judiciário, que assegura a imparcialidade jurisdicional, não é um fim em si mesmo, como defendiam e ainda defendem interesses judiciais muitas vezes corporativos. É apenas um meio e, como tal, só se justifica se assegurar a liberdade dos cidadãos. Se a lentidão, a ineficiência e o déficit moral deturpam, dificultam ou mesmo impedem na prática a própria prestaçāo judicial, a liberdade dos cidadãos está afetada e a sociedade e os poderes da República têm o dever de rever, reformar e reinventar suas instituiçōes:

O que não quer dizer que a defesa da independência do Poder Judiciário seja sempre uma defesa corporativa. Longe disto. Na verdade, o que houve histori- 
camente é fácil de entender. A defesa intransigente da independência do Poder Judiciário foi uma conseqüência necessária e direta dos anos de autoritarismo. Enquanto tal, foi e é uma defesa legítima dos juízes e da sociedade. Mas perde legitimidade quando apropriada por interesses corporativos. Como lembra o Ministro Peluso: "[...] os atuais instrumentos orgânicos de controle ético-disciplinar dos juízes, porque praticamente circunscritos às corregedorias, não são de todo eficientes, sobretudo nos graus superiores de jurisdição, como já o admitiram com louvável sinceridade os próprios magistrados, em conhecido estudo de Maria Tereza Sadek". Citando Nicoló Trocker, cbserva também que "o privilégio da substancial irresponsabilidade do magistrado não pode constituir o preço que a coletividade é chamada a pagar, em troca da independência dos seus juízes".

Por outro lado, o voto faz uma correta releitura aplicada do princípio da separação dos poderes, indo de Montesquieu a Kelsen e aos founding fathers e, sobretudo, a Loewenstein, quando diz: "la libertad es el telos ideológico de la separación de poderes". Ou seja: ao contrário do que o argumento corporativo prega, o que preocupava Montesquieu e seus seguidores era a liberdade dos cidadãos, ameaçada pela excessiva independência do poder. A técnica da separação não foi criada para multiplicar por três a independência absoluta de um poder. Ao contrário, a separação é um instrumento de limite e não de expansão de poderes, sejam eles quais forem, do Judiciário inclusive. O bem jurídico democrático prioritário a proteger não é a independência sem limites de qualquer poder, mas a liberdade da cidadania, que é afetada quando o conceito de independência do poder se absolutiza. $O$ direito do cidadão à imparcialidade jurisdicional ameaça ficar prejudicado - seja por motivos gerenciais, seja por motivos éticos - em nome da independência absoluta. O Min. Peluso oportunamente nos faz reler este conceito à luz de sua finalidade maior.

Finalmente, a terceira maneira de se entender este voto é entender o quanto revela de seu relator. Revela-o, por exemplo, como um adepto de Liebman, quando o cita: "As formas são necessárias, mas o formalismo é uma deformação." Isto porque a AGU pretendia que os pedidos da Associação dos Magistrados Brasileiros fossem julgados juridicamente impossíveis, pois deduzidos antes da publicaçāo oficial da Emenda [...] Publicamente aprovada e publicada antes do próprio voto. Ou seja, por um formalismo processual pretendia-se adiar uma decisão que não só a magistratura, mas o país, já esperava há décadas. O Ministro recusa esse formalismo excessivo.

Revela-o também no exercer o seu ofício, no ser um dos magistrados supremos da nação que julgam a causa "perante a Constituição". E não perante suas passadas conviç̧ōes pessoais. Nas palavras de Peluso: "Eu próprio jamais escondi oposição viva, menos à necessidade de ressurreição ou criação de um órgão incumbido do controle nacional da magistratura, do que ao perfil que se projetava ao Conselho e às prioridades de uma reforma que, ao meu sentir, andava ao largo das duas mais candentes frustraçōes do sistema, a marginalização histórica das classes desfavorecidas no acesso à jurisdição e a morosidade atávica dos proces- 
sos." O Ministro relativiza seus sentimentos e predileções pessoais ao ter de abrir os "ouvidos sacerdotais ao apelo de outras vozes", citando Benjamin Cardozo.

Este depoimento é muito importante porque, hoje, a perspectiva que politiza excessivamente qualquer voto de qualquer ministro do Supremo tende a entendêlo a partir de uma simples relação causal. Dize-me o Presidente que lhe nomeou e eu lhe direi como o ministro vota. Esta interpretação é eticamente errada e historicamente não comprovada. Nossos Ministros têm dado provas de uma independência não só em relação aos seus sentimentos e predileções pessoais, mas também a previsões mecanicistas. Adauto Lúcio Cardoso que o diga.

Este voto responde, pois, a uma urgência nacional ao mesmo tempo prática um Judiciário mais poderoso, ético, eficiente e transparente - e teórica - um princípio de separação de poderes subordinado prioritariamente à defesa da liberdade e da cidadania.

\section{EMENTA}

1. AÇÃO. Condição. Interesse processual, ou de agir. Caracterização. Ação direta de inconstitucionalidade. Propositura antes da publicaçāo oficial da Emenda Constitucional no 45/2004. Publicação superveniente, antes do julgamento da causa. Suficiência. Carência da ação não configurada. Preliminar repelida. Inteligência do art. 267, VI, do CPC. Devendo as condições da ação coexistir à data da sentença, considera-se presente o interesse processual, ou de agir, em ação direta de inconstitucionalidade de Emenda Constitucional que só foi publicada, oficialmente, no curso do processo, mas antes da sentença.

2. INCONSTITUCIONALIDADE. Ação direta. Emenda Constitucional $\mathrm{n}^{\underline{p}}$ 45/2004. Poder Judiciário. Conselho Nacional de Justiça. Instituição e disciplina. Natureza meramente administrativa. Órgão interno de controle administrativo, financeiro e disciplinar da magistratura. Constitucionalidade reconhecida. Separação e independência dos Poderes. História, significado e alcance concreto do princípio. Ofensa a cláusula constitucional imutável (cláusula pétrea). Inexistência. Subsistência do núcleo político do princípio, mediante preservação da função jurisdicional, típica do Judiciário, e das condições materiais do seu exercício imparcial e independente. Precedentes e súmula 649. Inaplicabilidade ao caso. Interpretação dos arts. $2^{\circ}$ e $60, \$ 4^{\circ}$, III, da CF: Ação julgada improcedente. Votos vencidos. São constitucionais as normas que, introduzidas pela Emenda Constitucional $n^{\circ}$ 45 , de 8 de dezembro de 2004, instituem e disciplinam o Conselho Nacional de Justiça, como órgão administrativo do Poder Judiciário nacional.

3. PODER JUDICIÁRIO. Caráter nacional. Regime orgânico unitário. Controle administrativo, financeiro e disciplinar. Órgão interno ou externo. Conselho de Justiça. Criação por Estado membro. Inadmissibilidade. Falta de competência constitucional. Os Estados membros carecem de competência constitucional para 
instituir, como órgão interno ou externo do Judiciário, conselho destinado ao controle da atividade administrativa, financeira ou disciplinar da respectiva Justiça. Supremo Tribunal Federal - Diário da Justiça de 17-3-2006 - ADI 3.367/DF.

4. PODER JUDICIÁRIO. Conselho Nacional de Justiça. Órgão de natureza exclusivamente administrativa. Atribuições de controle da atividade administrativa, financeira e disciplinar da magistratura. Competência relativa apenas aos órgãos e juízes situados, hierarquicamente, abaixo do Supremo Tribunal Federal. Preeminência deste, como órgão máximo do Poder Judiciário, sobre o Conselho, cujos atos e decisōes estão sujeitos a seu controle jurisdicional. Inteligência do art. 102, caput, inc. I, letra $r$, e $\$ 4^{\circ}$, da CF. O Conselho Nacional de Justiça não tem nenhuma competência sobre o Supremo Tribunal Federal e seus ministros, sendo esse o órgão máximo do Poder Judiciário nacional, a que aquele está sujeito.

5. PODER JUDICIÁRIO. Conselho Nacional de Justiça. Competência. Magistratura. Magistrado vitalício. Cargo. Perda mediante decisão administrativa. Previsão em texto aprovado pela Câmara dos Deputados e constante do Projeto que resultou na Emenda Constitucional $n^{9} 45 / 2004$. Supressão pelo Senado $\mathrm{Fe}-$ deral. Reapreciação pela Câmara. Desnecessidade. Subsistência do sentido normativo do texto residual aprovado e promulgado (art. 103-B, $\$ 4^{\circ}$, III). Expressão que, ademais, ofenderia o disposto no art. 95, I, parte final, da CF. Ofensa ao art. $60, \S 2^{\circ}$, da CF. Não ocorrência. Argüição repelida. Precedentes. Não precisa ser reapreciada pela Câmara dos Deputados expressão suprimida pelo Senado Federal em texto de projeto que, na redação remanescente, aprovada de ambas as Casas do Congresso, não perdeu sentido normativo.

6. PODER JUDICIÁRIO. Conselho Nacional de Justiça. Membro. Advogados e cidadãos. Exercício do mandato. Atividades incompatíveis com tal exercício. Proibição não constante das normas da Emenda Constitucional n 45/2004. Pendência de projeto tendente a torná-la expressa, mediante acréscimo de $₫ 8^{\circ}$ ao art. 103-B da CF. Irrelevância. Ofensa ao princípio da isonomia. Nāo ocorrência. Impedimentos já previstos à conjugação dos arts. 95 , parágrafo único, e $127, \mathbb{5}$, II, da CF. Ação direta de inconstitucionalidade. Pedido aditado. Improcedência. Nenhum dos advogados ou cidadãos membros do Conselho Nacional de Justiça pode, durante o exercício do mandato, exercer atividades incompatíveis com essa condição, tais como exercer outro cargo ou função, salvo uma de magistério, dedicar-se à atividade político-partidária e exercer a advocacia no território nacional.

\section{Relatório e Voto}

Trata-se de ação direta de inconstitucionalidade, com pedido de liminar, movida pela Associação dos Magistrados Brasileiros (AMB) e voltada contra os arts. $1^{\circ}$ e $2^{\circ}$ da Emenda Constitucional $n^{\circ}$ 45/2004, nos textos que, exteriorizando normas relativas ao Conselho Nacional de Justiça, são os seguintes: "Art. 103-B. O Conselho Nacional de Justiça compõe-se de quinze membros com mais de trin- 
ta e cinco e menos de sessenta e seis anos de idade, com mandato de dois anos, admitida uma recondução, sendo: I - um Ministro do Supremo Tribunal Federal, indicado pelo respectivo tribunal; II - um Ministro do Superior Tribunal de Justiça, indicado pelo respectivo tribunal; III - um Ministro do Tribunal Superior do Trabalho, indicado pelo respectivo tribunal; IV - um desembargador de Tribunal de Justiça, indicado pelo Supremo Tribunal Federal; V - um juiz estadual, indicado pelo Supremo Tribunal Federal; VI - um juiz de Tribunal Regional Federal, indicado pelo Superior Tribunal de Justiça; VII - um juiz federal, indicado pelo Superior Tribunal de Justiça; VIII - um juiz de Tribunal Regional do Trabalho, indicado pelo Tribunal Superior do Trabalho; IX - um juiz do trabalho, indicado pelo Tribunal Superior do Trabalho; X - um membro do Ministério Público da Uniāo, indicado pelo Procurador-Geral da República; XI - um membro do Ministério Público estadual, escolnido pelo Procurador-Geral da República dentre os nomes indicados pelo órgão competente de cada instituição estadual; XII - dois advogados, indicados pelo Conselho Federal da Ordem dos Advogados do Brasil; XIII - dois cidadãos, de notável saber jurídico e reputação ilibada, indicados um pela Câmara dos Deputados e outro pelo Senado Federal. $\$ 1^{\circ}$ O conselho será presidido pelo Ministro do Supremo Tribunal Federal, que votará em caso de empate, ficando excluído da distribuição de processos naquele tribunal. $\$ 2^{\circ}$ Os membros do Conselho serão nomeados pelo Presidente da República, depois de aprovada a escolha pela maioria absoluta do Senado Federal. $\$ 3^{\circ}$ Não efetuadas, no prazo legal, as indicações previstas neste artigo, caberá a escolha ao Supremo Tribunal Federal. $\$ 4^{0}$ Compete ao Conselho o controle da atuação administrativa e financeira do Poder Judiciário e do cumprimento dos deveres funcionais dos juízes, cabendo-lhe, além de outras atribuições que lhe forem conferidas pelo Estatuto da Magistratura: I - zelar pela autonomia do Poder Judiciário e pelo cumprimento do Estatuto da Magistratura, podendo expedir atos regulamentares, no âmbito de sua competência, ou recomendar providências; II - zelar pela observância do art. 37 e apreciar, de ofício ou mediante provocação, a legalidade dos atos administrativos praticados por membros ou órgãos do Poder Judiciário, podendo desconstituí-los, revê-los ou fixar prazo para que se adotem as providências necessárias ao exato cumprimento da lei, sem prejuízo da competência do Tribunal de Contas da União; IIl - receber e conhecer das reclamaçōes contra membros ou órgãos do Poder Judiciário, inclusive contra seus serviços auxiliares, serventias e órgãos prestadores de serviços notariais e de registro que atuem por delegação do poder público ou oficializados, sem prejuízo da competência disciplinar e correicional dos tribunais, podendo avocar processos disciplinares em curso e determinar a remoção, a disponibilidade ou a aposentadoria com subsídios ou proventos proporcionais ao tempo de serviço e aplicar outras sanções administrativas, assegurada ampla defesa; IV - representar ao Ministério Público, no caso de crime contra a administração pública ou de abuso de autoridade; $\mathrm{V}$ - rever, de ofício ou mediante provocação, os processos disciplinares de juízes e membros de tribunais julgados há menos de um ano; VI - elaborar semestralmente relatório estatístico sobre processos e sentenças prolatadas, por unidade da Federação, nos diferentes órgãos 
do Poder Judiciário; VII - elaborar relatório anual, propondo as providências que julgar necessárias, sobre a situação do Poder Judiciário no País e as atividades do Conselho, o qual deve integrar mensagem do Presidente do Supremo Tribunal Federal a ser remetida ao Congresso Nacional, por ocasião da abertura da sessão legislativa. $\$ 5^{\circ} \mathrm{O}$ Ministro do Superior Tribunal de Justiça exercerá a funçāo de Ministro-Corregedor e ficará excluído da distribuição de processos no Tribunal, competindo-lhe, além das atribuições que lhe forem conferidas pelo Estatuto da Magistratura, as seguintes: I - receber as reclamações e denúncias, de qualquer interessado, relativas aos magistrados e aos serviços judiciários; II - exercer funções executivas do Conselho, de inspeção e de correição geral; III - requisitar e designar magistrados, delegando-lhes atribuições, e requisitar servidores de juizos ou tribunais, inclusive nos Estados, Distrito Federal e Territórios. $\$ 6^{\circ}$ Junto ao Conselho oficiarão o Procurador-Geral da República e o Presidente do Conselho Federal da Ordem dos Advogados do Brasil. $\$ 7^{\circ}$ A Uniāo, inclusive no Distrito Federal e nos Territórios, criará ouvidorias de justiça, competentes para receber reclamaçōes e denúncias de qualquer interessado contra membros ou órgãos do Poder Judiciário, ou contra seus serviços auxiliares, representando diretamente ao Conselho Nacional de Justiça." "Art. 52. [...] II - processar e julgar os Ministros do Supremo Tribunal Federal, os membros do Conselho Nacional de Justiça e do Conselho Nacional do Ministério Público, o Procurador-Geral da República e o Advogado-Geral da União nos crimes de responsabilidade;" (grifo nosso) "Art. 92. [...] 1-A - o Conselho Nacional de Justiça; $\$ 1^{\circ}$ O Supremo Tribunal Federal, o Conselho Nacional de Justiça e os Tribunais Superiores têm sede na Capital Federal." (grifos nossos) "Art. 93 [...] III - o ato de remoção, disponibilidade e aposentadoria do magistrado, por interesse público, fundar-se-á em decisão por voto da maioria absoluta do respectivo tribunal ou do Conselho Nacional de Justiça, assegurada ampla defesa;" (grifo nosso) "Art. 102. [...] r) as ações contra o Conselho Nacional de Justiça e contra o Conselho Nacional do Ministério Público. (grifo nosso) “Art. 125. [...] $₫ 8^{\circ}$ Os Tribunais de Justiça criarão ouvidorias de justiça, competentes para receber reclamaçōes e denúncias de qualquer interessado contra membros ou órgão do Poder Judiciário, ou contra seus serviços auxiliares, representando diretamente ao Conselho Nacional de Justiça". (grifos nossos) Os fundamentos jurídicos do pedido podem ser reduzidos a dois argumentos substanciais: a instituição do Conselho Nacional de Justiça implicaria “(a) tanto inegável violação ao princípio da separação e da independência dos poderes (art. $2{ }^{\circ}$ da Constituição Federal), de que são corolários o auto-governo dos Tribunais e a sua autonomia administrativa, financeira e orçamentária (artigos 96, 99 e parágrafos, e $168 \mathrm{da}$ Constituição Federal), (b) como ainda a ofensa ao pacto federativo (artigos 18, 25 e 125), na medida em que submeteu os órgãos do Poder Judiciário dos Estados a uma supervisão administrativa, orçamentária, financeira e disciplinar por órgão da Uniāo Federal" (fls. 05).

Mas consta outro, tendente agora à decretação conjunta de inconstitucionalidade específica do art. 103-B, $\mathbb{\$} 4^{\circ}$, inc. III, objeto da mesma Emenda: sua redação final nāo teria sido submetida "à discussão e votação nas duas casas do Congresso $\mathrm{Na}$ - 
cional, mas apenas do Senado Federal, daí resultando a ofensa ao $\$ 2^{\circ}$, do art. 60 , da CF" (fls. 06). Em caráter liminar, aduzindo serem sólidos tais fundamentos e estar-se diante da "excepcional urgência" de que fala o art. $10, \$ 3^{\circ}$, da Lei $n^{\circ}$ 9.868/99, a autora pediu a imediata suspensão da "vigência dos dispositivos impugnados nesta ação, especialmente o art. 103-B", até o julgamento definitivo da causa (fls. 43-46). Entendendo tratar-se de matéria relevante e de "especial significado para a ordem social e a segurança jurídica", o Exmo. Sr. Presidente do Tribunal, a quem o feito foi remetido durante as férias (art. 13, inc. VIII, do RISTF), determinou o processamento da ação nos termos do art. 12 da Lei $n^{\circ}$ 9.868/99 (fls. 125). Sobrevieram, então, as informaçōes prestadas pelo Congresso (fls. 145-159), que respondeu a cada um dos argumentos da inicial e opinou pela total improcedência dos pedidos. De igual modo manifestaram-se a Advocacia-Geral da União e a Procuradoria-Geral da República (fls. 161-187 e 189-195). A primeira argüiu, em caráter preliminar, impossibilidade jurídica do pedido, uma vez que, à data da propositura da ação, a Emenda Constitucional impugnada não havia sido ainda publicada no Diário Oficial (fls. 164-167). VOTO. 1. Examino a preliminar. Argúi a Advocacia-Geral da Uniāo que os pedidos seriam "juridicamente impossíveis", porque deduzidos antes da publicação oficial da Emenda, coisa proibida no sistema de controle de constitucionalidade. Pede, em conseqüência, a extinção do processo, sem julgamento do mérito. Não obstante tenha razão o Advogado-Geral quanto à inadmissibilidade de controle de constitucionalidade em caráter preventivo, ao caso não quadra a conseqüência. Posto que, à data de propositura da ação, a Emenda Constitucional $n^{\circ} 45 / 2004$ não houvesse sido deveras publicada, foi-o pouco tempo depois, o que torna agora cognoscíveis os pedidos. A publicação superveniente da Emenda remediou a carência original da ação. A rigor, o vício processual imputado pela Advocacia-Geral ligava-se à suposta falta de interesse de agir, e não à impossibilidade jurídica dos pedidos. É que não se estava diante de inviabilidade teórica absoluta dos pedidos, nem doutra espécie de improcedência prima facie, que são as explicaçōes últimas da falta de possibilidade jurídica como uma das causas da chamada carência da ação. Tratar-se-ia, quando muito, de caso de desnecessidade da tutela jurisdicional, já que os textos impugnados ainda não tinham obtido existência jurídica. Mas, com a publicação subseqüente da Emenda, despontou pleno e nítido o interesse processual. Tem razão, ainda, o Advogado-Geral, quando afirma nāo serem, as regras processuais, meras formalidades, mas, sim, garantias do Estado democrático de direito (fls. 166). Equivoca-se, no entanto, ao tirar daí necessidade de extinçāo anômala do processo. Repugnaria ao sistema processual o decreto de carência. A falta de interesse de agir é posta como causa de trancamento do processo, porque a solução evita dispêndio inútil de tempo e energias na condução de uma causa insuscetível de produzir resultado prático ao autor. Não é este o caso, entretanto, pois a publicação da Emenda extirpou qualquer dúvida sobre a necessidade e a adequação dos pedidos. Fosse agora extinto o processo, a AMB retornaria de imediato a este juízo, com demanda idêntica, e ter-seiam, então, perdido tempo e esforços, em dano da parte e do ofício jurisdicional, em contraste aberto com os propósitos que norteiam a construção dogmática das 
condiçōes da ação. A respeito, merece lembrada a advertência de LIEBMAN: "as formas são necessárias, mas o formalismo é uma deformação". ${ }^{2} \mathrm{E}$ é bom não esquecer que as condições da ação devem coexistir ao tempo da decisão da causa. ${ }^{3}$ Rejeito a preliminar. 2. O tema nuclear da causa, a criação do Conselho Nacional de Justiça, órgão supostamente destinado a controle externo do Poder Judiciário, foi e continua sendo objeto de amplos debates nas mais diversas instâncias da sociedade brasileira. ${ }^{4}$ Dada a natureza mesma do assunto, em cujas entranhas situam-se matrizes fundamentais da nossa ordem jurídico-constitucional, que, com graves reflexos nas ações cotidianas, vão desde a divisão e o equilíbrio entre os Poderes até a estrutura e a independência do Poder Judiciário, nāo admira haja despertado e ainda desperte discussões fervorosas no ambiente político, no domínio acadêmico e, sobretudo, no seio da magistratura, da advocacia e, até, do Ministério Público. Eu próprio jamais escondi oposição viva, menos à necessidade da ressurreição ou criação de um órgão incumbido do controle nacional da magistratura do que ao perfil que se projetava ao Conselho e às prioridades de uma reforma que, a meu sentir, andava ao largo das duas mais candentes frustrações do sistema, a marginalizaçāo histórica das classes desfavorecidas no acesso à Jurisdição e a morosidade atávica dos processos. Não renuncio às minhas reservas cívicas, nem me retrato das críticas pré-jurídicas à extensão e à heterogeneidade da composição do Conselho. Mas isso não podia impedir-me, como meus sentimentos e predileçōes pessoais não me impediram nunca, em quatro lustros de ofício jurisdicional, de, atento à velha observação de CARDOZO, ter "aberto os ouvidos sacerdotais ao apelo de outras vozes", ciente de que "as palavras mágicas e as encantações são tão fatais à nossa ciência quanto a quaisquer outras". ${ }^{5}$ Julgo a causa perante a Constituição da República. 3. O argumento radical da autora vem da regra da separação, com os corolários da independência e harmonia entre os três Poderes da República (art. $2^{\circ}$ da Constituição Federal). Segundo a AMB, a instituição de órgão funcionalmente voltado ao "controle da atuação administrativa e financeira" do Judiciário e ao "cumprimento dos deveres funcionais" dos magistrados, mas composto por membros na origem alheios ao mesmo Poder - dois dos quais indicados pelo Legislativo -, violaria a dita cláusula pétrea da separação dos Poderes, em cujo ventre reside a garantia da independência do Judiciário. Essa postura da autora já desvela toda a preocupação - muito legítima, diga-se - de que o advento do Conselho Nacional de Justiça traduza sério risco à independência do Poder Judiciário, no exercício de sua função típica, a jurisdicional. É que, apenas para adiantar o que me parece o ponto nevrálgico da causa, ninguém tem dúvida de que nāo pode a

1 Manual de direito processual civil. Trad. Cândido Rangel Dinamarco. 2. ed. Rio de Janeiro: Forense, 1986 , v. 1, p. 258.

3 Cf., por todos, Dinamarco, Cândido Rangel. Instituições de direito processual civil. São Paulo: Malheiros, 2001 , v. 3, p. 143.

4 Veja-se SADEK, Maria Tereza. Controle externo do poder judiciário. In: Reforma do judiciário. São Paulo: Fundação Konrad Adenauer, 2001, passim.

5 CARDOZO, Benjamin N. A Natureza do processo e a evolução do Direito. Trad. Lêda Boechat Rodrigues. Sāo Paulo: Nacional de Direito, 1956, p. 144. 
independência do Judiciário, seja a externa, assim considerada a da instituição perante os demais Poderes e órgãos de pressão, seja a interna, a dos magistrados entre si, estar sob nenhum risco próximo nem remoto, porque, em resguardo da ordem jurídica e, ao cabo, da liberdade do povo, tal predicado constitui a fonte, o substrato e o suporte de todas as condições indispensáveis a que a atividade judicante seja exercida com a imparcialidade do tertius, sem a qual já se não concebe a jurisdição em nenhum Estado civilizado e, muito menos, no Estado democrático de direito. Retomarei logo mais o tema, bastando-me por ora reavivar esta inconcussa verdade político-jurídica: é na exata medida em que aparece como nítida e absolutamente necessária a garantir a imparcialidade jurisdicional que a independência do Judiciário e da magistratura guarda singular relevo no quadro da separação dos Poderes e, nesses limites, é posta a salvo pela Constituição da República. De modo que todo ato, ainda quando de cunho normativo de qualquer escalão, que tenda a romper o equilíbrio constitucional em que se apóia esse atributo elementar da funçāo típica do Poder Judiciário, tem de ser prontamente repelido pelo Supremo Tribunal Federal, como guardião de sua inteireza e efetividade. A independência suporta, na sua feição constitucional, teores diversos de autonomia administrativa, financeira e disciplinar. Na verdade, ela só pode ser considerada invulnerável, como predicado essencial do sistema da separação, quando concreta redução de seu âmbito primitivo importe, sem dano do equilíbrio e estabilidade entre os Poderes, transferência de prerrogativas a outro deles, ainda que nāo chegue a caracterizar submissão política. Ou, no que concerne ao Judiciário, quando outra forma de supressão de atribuiçōes degrade ou estreite a imparcialidade jurisdicional. Fora dessas hipóteses, nada obsta a que o constituinte reformador the redesenhe a configuração histórica, mediante reorganização orgânica e redistribuição de competências no âmbito da estrutura interna do Judiciário, sem perda nem deterioração das condições materiais de isenção e imparcialidade dos juízes. 4. À luz permanente dessa idéia, analiso a alegação de que a criação do Conselho Nacional de Justiça, com a estrutura e as competências outorgadas pela Emenda $\mathrm{n}^{\circ} 45 / 2004$, atentaria, mais que contra a norma do art. $2^{\circ} \mathrm{da}$ Carta, contra o autêntico sistema constitucional da separação dos Poderes. Nisso convém remontar, embora brevemente, às raízes históricas e à evolução da doutrina política que o inspira e explica. ${ }^{6}$ Apesar de ter adquirido consagração com a obra clássica de MONTESQUIEU, a teoria da separação dos poderes tem antecedentes antigos. Já ARISTÓTELES, na Política, defendia a idéia de que a concentração do poder político nas mãos de um só homem, "sujeito a todas as possiveis desordens e afeições da mente humana", era inconveniente, ${ }^{\top}$ e, com tal aviso, distinguia as funçōes do Estado em deliberante, executiva e judiciária. ${ }^{8}$ Foi na Era Moderna, entretanto,

\footnotetext{
- CELSO FERNANDES CAMPILONGO afirma cuidar-se de um dos conceitos mais complexos da teoria constitucional (Política, sistema jurídico e decisão judicial. São Paulo: Max Limonad, 2002, p. 30).

; Livro III, Capítulo XI. In: Aristóteles. São Paulo: Nova Cultural, 1999, p. 230-234.

8 LOEWENSTEIN, KARL. Teoría de la constitución. Traduçāo de Alfredo Gallego Anabitarte. Barcelona: Editorial Ariel, 1976, p. 57.
} 
que a divisão do exercício do poder principiou a tomar corpo, sobretudo no sulco da evolução política por que passou a Inglaterra até a edição do Bill of Rights, em 1689. Baseado na realidade inglesa do tempo, LOCKE formulou a primeira construção sistemática de uma teoria da separaçāo de poderes, dividindo-os em Legislativo, Executivo e Federativo. ${ }^{9}$ Ao primeiro competiria elaborar as leis que disciplinariam o uso da força na comunidade civil; ao segundo, aplicar as leis aos membros da comunidade; e ao terceiro, o desempenho da função de relacionamento com outros Estados. Não aparece, na obra do autor, o Poder Judiciário como corpo independente dos demais. ${ }^{10}$ Apesar de reputar diversas em si as funções representadas de cada um desses poderes, LOCKE entendia que o Executivo e o Federativo deveriam ser exercidos pela mesma pessoa. E subordinava-os ambos ao poder Legislativo, considerado supremo, sujeito apenas ao poder do próprio povo. Essencial, para ele, seria a separação entre os componentes do Legislativo e do Executivo:

"[...] como pode ser muito grande para a fragilidade humana a tentação de ascender ao poder, não convém que as mesmas pessoas que detêm o poder de legislar tenham também em suas mãos o poder de executar as leis, pois elas poderiam se (sic) isentar da obediência às leis que fizeram, e adequar a lei a sua vontade $[\ldots]^{\prime \prime}{ }^{11}$

Conquanto ainda estivessem algo distantes da fórmula clássica da tripartição dos poderes, cunhada depois por MONTESQUUIEU, essas teorizações já continham in nuce a idéia da necessária divisão funcional do poder político, porque não ficasse depositado em mãos únicas. Partiam da percepção empírica, mas sábia, de que o poder tende a desvios - a qual foi mais tarde sintetizada na máxima de LORD ACTON ("todo poder corrompe") -, e tinham em vista ideal político muito claro: evitar, em nome da preservação da liberdade, os excessos, abusos e inconvenientes do poder ilimitado; a arbitrariedade estatal, enfim. Foi o que norteou MONTESQUIEU. Ao propor a divisão das funções do Estado em legislativa, administrativa e jurisdicional, assim justificou a atribuição de cada uma a órgãos diferentes:

"La liberté politique, dans un citoyen, est cette tranquillite d'esprit qui provient de l' opinion que chacun a de sa sùreté; et, pour qu'on ait cette liberté, il faut que le gouvernement soit tel qu'un citoyen ne puisse pas craindre un autre citoyen. Lorsque dans la même personne ou dans le même corps de magistrature la puissance législative est réunie à la puissance exécutrice, il n'y a point de liberté, parce qu'on peut craindre que le même monarque ou le même sénat ne fasse des lois tyranniques pour les

9 Segundo tratado sobre o governo civil, XII, XIIl e XIV. In: Segundo tratado sobre o governo civil e outros escritos. Petrópolis: Vozes, 1994, p. 170-186.

10 GOUGH, j. W. Introdução ao Segundo tratado sobre o governo civil e outros escritos. Ob. cit., p. 30.

11 Ob. cit., p. 170. 
exécuter tyranniquement. Il n'y a point encore de liberté si la puissance de juger n'est pas séparée de la puissance législative et de l'exécutrice. Si elle étoit jointe à la puissance législative, le pouvoir sur la vie et la liberté des citoyens seroit arbitraire; car le juge seroit législateur. Si elle étoit jointe à la puissance exécutrice, le juge pourroit avoir la force d'un oppresseur. Tout seroit perdu si le même homme, ou le même corps des principaux, ou des nobles, ou du peuple, exerçoient ces trois pouvoirs: celui de faire des lois, celui d'exécuter les résolutions publiques, et celui de juger les crimes ou les différends des particuliers."12

"A liberdade política em um cidadão é aquela tranqüilidade de espírito que provém da convicção que cada um tem da sua segurança. Para ter-se essa liberdade, precisa que o Governo seja tal que cada cidadão não possa temer outro. Quando, na mesma pessoa ou no mesmo corpo de Magistratura, o Poder Legislativo é reunido ao Executivo, não há liberdade. Porque pode temer-se que o mesmo Monarca ou o mesmo Senado faça leis tirânicas para executá-las tiranicamente. Também não haverá liberdade se o Poder de Julgar não estiver separado do Legislativo e do Executivo. Se estivesse junto com o Legislativo, o poder sobre a vida e a liberdade dos cidadãos seria arbitrário: pois o Juiz seria Legislador. Se estivesse junto com o Executivo, o Juiz poderia ter a força de um opressor. Estaria tudo perdido se um mesmo homem, ou um mesmo corpo de principais (sic) ou de nobres, ou do Povo, exercesse estes três poderes: o de fazer as leis; o de executar as resoluções públicas; e o de julgar os crimes ou as demandas dos particulares." 13

Dessa velha liçāo vê-se que, ao arquitetar sua clássica teoria, MONTESQUIEU era movido de um só ânimo: repartir o exercício do poder entre pessoas distintas, a fim de impedir que sua concentração comprometesse a liberdade dos cidadãos. Contra os intuitivos abusos a que leva o poder incondicionado, sustentou a fórmula da tripartição das funções públicas, como mecanismo de limitação do poder e, conseqüentemente, garantia da liberdade individual. Nas palavras de LOEWENSTEIN: "la libertad es el telos ideológico de la teoria de la separación de poderes". ${ }^{14}$

A sintese de MONTESQUIEU é mais bem compreendida quando vista como proposição elementar, que era, de uma teoria política, antes que de teoria propriamente jurídica. $\mathrm{O}$ autor tinha os olhos postos na realidade política francesa, dentro da qual era ardoroso defensor do liberalismo na luta contra o absolutismo monárquico do Ancien Regime, ${ }^{15}$ segundo a moldura do conflito clássico entre liberdade e autoridade. Seu propósito original estava, assim, em combater o poder absoluto, menos que em preconizar umả técnica de organização racional das funções pú-

\footnotetext{
12 De l'esprit des lois. Paris: Garnier Fréres, s. d., p. 143.

13 O espírito das leis. Trad. Pedro Vieira Mota, 5. ed. São Paulo: Saraiva, 1998, p. 167-168.

14 Teoría de la constitución, ob. cit., p. 55.

15 RIBEIRO, Hélcio. Justiça e democracia: judicializaçāo da política e controle externo da magistratura. Porto Alegre: Síntese, 2001, p. 65.
} 
blicas. A idéia da tripartição dos poderes foi, portanto, o método lucubrado para a consecuçāo de um fim maior: limitar o poder político. Com a aparentemente exclusiva exceção de PASSERIN D' ENTRÈVES, ${ }^{16}$ é o que sempre professaram os estudiosos. Como afirma OTTO BACHOF: "el sentido de la división de poderes es impedir la concentración de poder $y$, con ello, un posible abuso del mismo". ${ }^{17}$

No mesmo sentido, ouça-se CARRÉ DE MALBERG:

“Et d'ailleurs, toute la démonstration de Montesquieu tourne autour de cette idée principale: assurer la liberte des citoyens, em leus fournissant par la séparation des pouvoirs la garantie que chacun de ceux-ci sera exercé légalement. [...] Seule, en effet, la séparation des pouvoirs peut fournir aux gouvernés une garantie sérieuse et une protection efficace."18

"Aliás, toda a argumentação de Montesquieu gira em torno desta idéia principal: assegurar a liberdade dos cidadãos, dispensando-lhes, por meio da separação dos poderes, a garantia de que cada um deles será exercido legalmente. [...] Portanto, somente a separação dos poderes pode dar aos governados uma garantia séria e uma proteção eficaz."

\section{Também, HANS KELSEN:}

“A significação histórica do princípio chamado 'separação de poderes' encontra-se precisamente no fato de que ele opera antes contra uma concentração que a favor de uma separação de poderes." 19

Mais enfáticos são ZAFFARONI e TÉRCIO SAMPAIO FERRAZ JÚNIOR. $O$ primeiro acentua:

“[...] as palavras de Montesquieu são muito mais claras se forem consideradas como provindas de um sociólogo e não como texto dogmático, porque parte ele do reconhecimento de um fenômeno humano que não pode ser esquecido na medida em que se conserve um mínimo de contacto com a realidade: todo poder induz ao abuso".

“[...] Entendendo Montesquieu sociológica e politicamente - e não jurídica ou formalmente - não resta dúvida de que ele quer significar que o poder deve estar distribuído entre órgãos ou corpos, com capacidade de regeremse de forma autônoma com relaçāo a outros órgãos ou corpos, de modo que se elida a tendência 'natural' ao abuso." 20

16 The notion of the state: an introduction to political theory. Oxford: Oxford University, 1967, p. 121.

1: Jueces y constitución. Trad. Rodrigo Bercovitz Rodríguez-Cano. Madrid: Civitas, 1985, p. 58.

18 Contribution a la théorie générale de l'état. Paris: Sirey, 1922, t. II, p. 7.

19 Teoria geral do direito e do estado. Traduçāo de Luís Carlos Borges. São Paulo: Martins Fontes/ Universidade de Brasília, 1990, p. 274.

20 Poder judiciário: crises, acertos e desacertos. Tradução de Juarez Tavares. São Paulo: Revista dos Tribunais, 1995, p. $81-83$. 
Remata o segundo: "Montesquieu, na verdade, via na divisão dos poderes muito mais um preceito de arte política do que um princípio jurídico. Ou seja, não se tratava de um princípio para a organização do sistema estatal e de distribuição de competências, mas um meio de se evitar o despotismo real.

[...] Nesse sentido, o princípio não era de separação de poderes, mas de inibição de um pelo outro de forma recíproca." 21

A matriz histórica da separação dos Poderes há de ser, pois, reconduzida, no contexto da causa, ao alcance de instrumento político que lhe emprestava o autor que a consagrou como teoria: conter o poder, para garantir a liberdade. E esta a razāo por que, em coerência com seus pressupostos teóricos e objetivos práticos, MONTESQUIEU jamais defendeu a idéia de uma separação absoluta e rígida entre os órgãos incumbidos de cada uma das funções estatais. Antes, chegou a fazer referência a mecanismos de relacionamento mútuo entre os poderes, a fim, precisamente, de lhes prevenir abusos no exercício. Contra a natural tendência de expansão do poder, era mister a criação de instrumentos que garantissem a subsistência do esquema tripartite de funções, impedindo que os representantes de uma delas se sobrepusessem aos demais. Doutro modo, o poder incontido sacrificaria a liberdade. E exemplo significativo de relaçōes dessa espécie, colhido à obra do grande pensador francês, é a intervenção do Executivo no processo legislativo mediante o veto. ${ }^{22}$

Discorrendo sobre o pensamento de MONTESQUIEU, CARRÉ DE MALBERG realça-lhe essa idéia:

"La doctrine de Montesquieu se rattache donc essentiellement au système de l' État de droit'. Cependant, par la force des choses, cette doctrine, bien que visant principalement à sauvegarder la liberté civile, implique aussi certaines dispositions à prendre, em vue d' assurer la liberté des autorités publiques elles-mêmes, dans leurs rapports les unes avec les autres, en tant qu'il s'agit, pour chacune d'elles, de l'exercice du pouvoir qui lui est spécialement attribué. C'est là un nouvel aspect, fort important, du sujet. En effet, la division des compétences et la spécialisation des fonctions ne saurient, à elles seules, suffire à réaliser la limitation des pouvoirs: pour que cette limitation se trouve assurée, il faut, en outre, qu'aucun des trois ordres de titulaires des pouvoirs ne possède ou ne puisse acquérir de supériorité, qui lui permettrait de dominer les deux autres et qui, par lá même, pourrait peu à peu dégénérer en omnipotence. Et pour cela, il est indispensable que les titulaires des trois pouvoirs soient, non seulement investis de compétences distinctes et séparées, mais encore rendus, par

21 O judiciário frente à divisāo dos poderes: um princípio em decadência? In: Revista trimestral de direito.

22 Cf. FERREIRA FILHO, Manoel Gonçalves. Curso de direito constitucional. 24. ed. São Paulo: Saraiva, 1997, p. 133. 
leur constitution organique, indépendants et comme égaux les uns vis-àvis des autres. Ce n'est qu'à cette condition qu'ils pourront effectivement se limiter et s'arrêter entre eux." 23

"A doutrina de Montesquieu liga-se, portanto, essencialmente ao sistema do 'Estado de direito'. Entretanto, pela força das coisas, essa doutrina, embora vise principalmente a salvaguardar a liberdade civil, implica também certas disposições por tomar, no intuito de assegurar a liberdade das autoridades públicas elas mesmas, nas relaçōes umas com as outras, quanto se trate, para cada qual, do exercício do poder que lhe é especialmente atribuído. Aí está novo aspecto, extremamente importante, do tema. A divisāo das competências e a especializaçāo das funçōes nāo seriam deveras, sozinhas, suficientes para realizar a limitaçāo dos poderes: para que tal limitação seja garantida, é preciso, além disso, que nenhuma das três ordens de titulares dos poderes possua ou possa adquirir superioridade que lhe permita dominar os outros dois e que, conseqüentemente, poderia pouco a pouco degenerar em onipotência. E, para isso, é indispensável que os titulares dos três poderes sejam, não somente investidos de competências distintas e separadas, mas também feitos, por sua constituição orgânica, independentes e iguais uns frente aos outros. É somente nessa condição que eles poderão efetivamente limitar-se e deter-se entre si." Recuperada a ratio que orientou MONTESQUIEU, qual seja, garantir a liberdade civil por meio da contenção do poder político, não admira nem surpreende não tenha ele proposto separação absoluta entre as funçōes públicas, até porque relaçōes recíprocas entre os Poderes são, do ponto de vista funcional, imprescindiveis à economia do próprio sistema, pois também tendem a prevenir que as necessidades concretas de seu exercício sirvam de pretexto a que um se avantaje aos outros. Observa ZAFFARONI: "Não há em Montesquieu qualquer expressão que exclua a possibilidade dos controles recíprocos, nem que afirme uma absurda compartimentalização que acabe em algo parecido com 'três governos' e, menos ainda, que não reconheça que no exercício de suas funçōes próprias esses órgãos nāo devam assumir funçōes de outra natureza." ${ }^{24}$

Nada disto é novidade. Mas há, aqui, toda a pertinência em relembrá-lo, porque tal pensamento, não apenas seduziu, mas guiou, na talvez mais bem-sucedida simplificação orgânico-funcional e aplicação histórica da teoria, seus mais agudos comentadores e responsáveis pela difusāo do sistema nas modernas constituições ocidentais: ALEXANDER HAMILTON, JAMES MADISON e JOHN JAY. Vale a pena rever como se pronunciaram os "Founders", nos panfletários artigos federalistas: "Portanto, visto que estes fatos foram o norte de Montesquieu para

\footnotetext{
23 Ob. cit., p. 8.

24 Ob. cit., p. 82-83.
} 
estabelecer o principio de que se trata, podemos concluir que, quando ele estabeleceu 'que não há liberdade todas as vezes que a mesma pessoa ou a mesma corporação legisla e executa ao mesmo tempo, ou por outras palavras, quando o poder de julgar nāo está bem distinto e separado do Legislativo e Executivo', não quis proscrever toda a ação parcial, ou toda a influência dos diferentes poderes uns sobre os outros; o que quis dizer, segundo se colige das suas expressões, e ainda melhor dos exemplos que lhe serviram de regra, foi que, quando dois poderes, em toda a sua plenitude, se acham concentrados numa só māo, todos os princípios de um governo livre ficam subvertidos." ${ }^{25} \mathrm{E}$, mais adiante, concluem: "Fica provado no capítulo antecedente que o axioma político que se examina não exige a separação absoluta dos três poderes; demonstrar-se-á agora que sem uma tal ligação que dê a cada um deles o direito constitucional de fiscalizar os outros, o grau de separação, essencial à existência de um governo livre, não pode na prática ser eficazmente mantido". ${ }^{26}$

Esse conjunto de idéias foi o substrato teórico que governou os federalistas na engenharia do esquema de contenções e compensações que, figuradas nos "checks and balances", concretizaram a mais curial resposta política à necessidade da existência de expedientes de controle mútuo entre os poderes, para que nenhum transpusesse seus limites institucionais. Sem descurar o dogma da separação entre as funções, que as quer independentes e bem definidas, sublinharam toda a importância dos instrumentos de fiscalizaçāo recíproca, como peças essenciais na engrenagem da divisão e do equilíbrio entre elas, a serviço da resistência à intrusão e à tirania. A respeito dessa configuração prática, notava COOLEY, ainda no século XIX: “This arrangement gives each department a certain independence, which operates as a restraint upon such action of the others as might encroach on the rights and liberties of the people, and makes it possible to establish and enforce guaranties against attempts at tyranny. We thus have the checks and balances of government, which are supposed to be essential to free institutions."27

"Esse arranjo confere a cada poder certa independência, que opera como um freio à ação dos outros que possa interferir nos direitos e liberdades das pessoas, e torna possivel o estabelecimento e implementação de garantias contra tentativas de tirania. Temos, assim, freios e contrapesos de governo, que se reputam essenciais a instituições livres."

Com tal roupagem, a receita política de MONTESQUIEU, acolhida já na Declaração de Direitos da Virgínia, em 1776, incorporou-se em boa parte das Constituições ocidentais, a principiar pela americana. E sua menção na Declara-

25 O federalista. Traduçāo de Hiltomar Martins Oliveira. Belo Horizonte: Líder, 2003, p. 299-300. Grifos nossos.

26 Ob. cit., p. 305. Grifos nossos.

2- COOLEY, Thomas M. General principles of constitutional law. 2. ed. Boston: Little, Brown and Company, 1891, p. 41 (reimpressāo de 1998). 
ção dos Direitos do Homem e do Cidadão, de 1789, contribuiu decisivamente para a transformar em dogma da teoria constitucional. ${ }^{28}$

Isso, é óbvio, não significa que se lhe tenham manifestado de modo homogêneo as configurações históricas nos textos constitucionais, como se fossem adaptações mecânicas de um modelo de contornos acabados. Ajustando-se às tradiçōes culturais, à realidade política e ao próprio arcabouço institucional de cada país, o grau de autonomia dos poderes e os mecanismos possíveis de controle recíproco variam muito em cada um dos sistemas jurídico-constitucionais que adotam $o$ postulado político da separação, oscilando, especialmente, entre os modelos integrados à tradiçāo do constitucionalismo francês e do norte-americano. E é natural que assim seja. Afinal, como diz OTTO BACHOF, "no existe ningún esquema patenteado de división de poderes que pueda funcionar en todas las épocas y bajo los más diversos supuestos sociales". ${ }^{29}$

Mas, a afirmação do princípio como ingrediente axiomático da definição e estrutura dos Estados democráticos, essa sobrevive às diferenças sociais e aos rumos da evolução política, a despeito das variaçōes que lhe determinam tais vicissitudes históricas. 4. Diante dessas premissas, é preciso, então, apurar as feições particulares que tomou o princípio em nossa Constituição Federal. Como pontua HESSE, ${ }^{30}$ a identificação do conteúdo desse postulado histórico não pode prescindir da análise da configuraçāo e dos contornos que lhe dá a ordem jurídica concreta de certo Estado. De modo que só o exame da sua concreta disposição na ordem jurídica vigente permitirá aferir se a instituição do Conselho Nacional de Justiça insulta, ou não, o sistema positivo da separação e independência dos Poderes. Já o tinha advertido o Min. GILMAR MENDES, quando ainda ocupava o cargo de Advogado-Geral da União: “[...] o contraste entre a norma questionada e o parâmetro constitucional da divisão de poderes é uma operação de índole normativa e valorativa, que, por isso, deve levar em conta não uma concepção abstrata do princípio de divisão de poderes, mas seu conteúdo efetivo na ordem constitucional positiva" (apud ADI no 135 , voto do Rel. Min. OCTÁvIO GALLOTTI, $D J$ de 15-8-97). Ninguém tampouco tem dúvidas acerca da superior importância atribuída pela Constituição Federal às normas da separação dos Poderes, em conformidade, aliás, com nossa tradiçāo republicana. Já no art. $2^{\circ}$, estatui: "são Poderes da União, independentes e harmônicos entre si, o Legislativo, o Executivo e o Judiciário". E logo o sublima a cláusula irremovível, vedando, no art. $60, \$ 4^{\circ}$, inc. III, seja "objeto de deliberação a proposta de emenda tendente a abolir: [...] III - a separação dos Poderes". Donde se tem logo por indiscutível que o princípio da separação e independência dos Poderes integra a ordem constitucional positiva, em plano

\footnotetext{
28 SILVA, José Afonso da. Curso de direito constitucional positivo. 18. ed. São Paulo: Malheiros, 2000, p. 113.

29 Ob. cit., p. 58.

30 HESSE, Konrad. Elementos de direito constitucional da República Federal da Alemanha. Tradução de Luís Afonso Heck. Porto Alegre: Sergio Antonio Fabris, 1998, p. 9.368.
} 
sobranceiro. E, nessa perspectiva, cada um deles tem sua organização regulada em capítulo distinto no Título IV: arts. 44 a 75 (Legislativo), arts. 76 a 91 (Executivo) e arts. 92 a 135 (Judiciário). Ora, é o confronto analítico dos preceitos relativos à organização e ao iuncionamento de cada uma dessas funções públicas que permite extrair o conteúdo e a extensão de que se reveste a teoria da separação em nosso sistema jurídico-constitucional. Noutras palavras, é seu tratamento normativo, através de todo o corpo constitucional, que nos dá o sentido e os limites dos predicados da independência e da harmonia, previstos no art. $2^{\circ}$. E o que se lhe vê é que o constituinte desenhou a estrutura institucional dos Poderes de modo a garantir-lhes a independência no exercício das funções típicas, mediante previsão de alto grau de autonomia orgânica, administrativa e financeira. Mas tempera-o com a prescrição doutras atribuições, muitas das quais de controle recíproco, e cujo conjunto forma, com as regras primárias, verdadeiro sistema de integração e cooperação, preordenado a assegurar equilíbrio dinâmico entre os órgãos, em benefício do escopo último, que é a garantia da liberdade. Esse quadro normativo constitui expressão natural do princípio na arquitetura política dos freios e contrapesos. À Constituição repugna-lhe toda exegese que reduza a independência dos Poderes a termos absolutos, os quais, aliás de todo estranhos aos teóricos de sua fórmula, seriam contraditórios com a idéia que a concebeu como instrumento político-liberal. Confirma-o rápido percurso pelo texto constitucional. Não são poucos os institutos cuja disciplina revela ostensiva existência de mecanismos predispostos ao controle mútuo entre os Poderes e, até, ao desempenho anômalo, por um deles, de função típica de outro. Basta mencionar o veto (arts. $66, \$ 1^{\circ}$, e 84 , inc. V), o impeachment (arts. 52, 85 e 86), o controle de constitucionalidade das leis (arts. 102, I, letra $a$, e 103), as medidas provisórias (art. 62), as leis delegadas (art. 68), o poder conferido ao Legislativo de sustar atos normativos do Executivo (art. 49, inc. $\mathrm{V}$ ), bem como de lhe fiscalizar e controlar os atos (inc. X), o controle das contas públicas pelo Congresso Nacional e pelo Tribunal de Contas (arts. 70, 71, cc. 49, inc. IX), o Conselho da República (art. 89), o poder do Presidente da República de conceder indulto e comutar penas (art. 84, inc. XII) etc. Não menos significativa é a previsão do procedimento de elaboração conjunta do orçamento de cada Poder, por meio da lei de diretrizes orçamentárias e da própria lei orçamentária (arts. 48, inc. II, e 99, 165 a 168). No que concerne à vida orgânica do Judiciário, merece atenção especial a competência do Executivo para nomear parte dos membros do Poder, como se dá com integrantes da Justiça Eleitoral (arts. 119, inc. II, e 120, inc. III), dos Tribunais Regionais Federais, dos Tribunais estaduais e do Distrito Federal, por via do chamado quinto constitucional (art. 94), e dos próprios Ministros desta Casa, cuja investidura depende ainda de aprovação do Senado (art. 101, $\$$ único). Todos esses exemplos provam, ad rem, que a incorporação privilegiada do princípio da separação na ordem constitucional não significa de modo algum que a distribuição primária das funções típicas e a independência formal dos Poderes excluam regras doutro teor, que, suposto excepcionais na aparência, tendem, no fundo, a reafirmar a natureza unitária das funções estatais, a cuja repartição orgânica é imanente a vocação conjunta de instrumentos da liberdade e da cidadania. 
Tal arrumação normativa está longe de fraturar ou empobrecer o núcleo político e jurídico do sistema, que só estará mortalmente ferido lá onde se caracterizar, à luz de sua inspiração primordial, usurpação de funçōes típicas ou aniquilamento prático da autonomia de cada Poder. É essa, de certo modo, a opiniāo comum dos constitucionalistas pátrios. ${ }^{31}$

E, ao propósito, nossa experiência constitucional em nada destoa do que se verifica alhures. Reconhece, em caráter geral, WILLIAM PRILLAMAN que: "[...] no branch or agent of government in a separation of powers system is completely 'independent' from the other branches. Courts rely on other branches of government for their budgets and enforcement of their rulings; the judicial nomination process often depends on executive nomination and legislative approval; and appointees may be subject to legislative impeachment. Thus, no judiciary is completely removed from the affairs of the more political departments of government". ${ }^{32}$

“[...] nenhum ramo ou agente de governo, em um sistema de separação de poderes, é completamente 'independente' dos outros. As cortes dependem de outros setores do governo tanto para aprovação de seus orçamentos, como para o cumprimento de suas decisões; o processo de nomeação judicial freqüentemente depende de nomeação do Executivo e aprovação do Legislativo; e os indicados podem ainda ser submetidos ao impeachment legislativo. Assim, nenhum Judiciário está completamente afastado dos assuntos dos ramos mais políticos do governo." Sob o prisma constitucional brasileiro do sistema da separação dos Poderes, não se vê a priori como possa ofendê-lo a criação do Conselho Nacional de Justiça. À luz da estrutura que lhe deu a Emenda Constitucional no 45/2004, trata-se de órgão próprio do Poder Judiciário (art. 92, I-A), composto, na maioria, por membros desse mesmo Poder (art. 103-B), nomeados sem interferência direta dos outros Poderes, dos quais o Legislativo apenas indica, fora de seus quadros e, pois, sem laivos de representação orgânica, dois dos quinze membros. Brandida como argumento exemplar e capital da pretensa inconstitucionalidade do Conselho, tal indicação em si, em que qualquer crítico desapaixonado enxergaria, quando muito, mera representaçāo simbólica da instância legislativa, não pode equiparar-se a nenhuma forma de intromissão incompatível com a idéia política e o perfil constitucional da separação e independência dos Poderes. O preceito que a estabelece não inova coisa alguma na ordem constitucional, em cujo contexto guarda, com ruidosa clareza, menor extensão lógica e índice muito mais modesto de participação doutro Poder no processo de escolha de membros do Poder ju-

31 SILVA, José Afonso da. Ob. cit., p. 113-115. FERREIRA FILHO, Manoel Gonçalves. Ob. cit., p. 133. BASTOS, Celso Ribeiro. Curso de direito constitucional. 22. ed. São Paulo: Saraiva, 2001, p. 166.

32 The judiciary and democratic decay in Latin America: declining confidence in the rule of law. Westport: Praeger, 2000, p. 16. 
diciário, do que, por exemplo, o velhíssimo modelo do art. 101, parágrafo único, da Constituição da República, o qual defere ao Chefe do Executivo competência exclusiva para nomear todos os integrantes desta Casa! Têm, nesse claro sentido, sabor apenas didático, as observaçōes de ANTONIO CARLOS DE ARAÚJO CINTRA, ADA PELLEGRINI GRINOVER e CÂNDIDO RANGEL DINAMARCO, de que "[...] prevalece entre nós, quanto ao Supremo Tribunal Federal e aos tribunais superiores federais, o sistema de nomeação dos magistrados pelo Executivo, com aprovação do Senado Federal. É por isso que a independência do Judiciário, absoluta quanto ao exercício de suas funçōes, não o é no que respeita à constituição dos tribunais". 33

Seria, deveras, fraqueza de espírito insistir na demonstração do absurdo lógico-jurídico que estaria em dar, sob pretexto de usurpação de poderes, pela inconstitucionalidade da criação do Conselho, sem antes reconhecê-la, com maiores e mais conspícuas razões, ao processo de nomeação de todos os ministros do Supremo Tribunal Federal. A fortiori, esta conclusão óbvia não apenas decepa a objeção de inconstitucionalidade específica a título de injúria ao sistema da separação e independência dos Poderes, mas, sobretudo, é prova suficiente de que não há nenhuma, ainda quando genérica, por conta dessa mesma causa material, nas regras de composição, escolha e nomeação dos membros do Conselho. Donde vem, logo, o erro de o tomar por órgão de controle externo. Talvez ocorra a alguém que, na prática, essa composição híbrida poderia comprometer a independência interna e externa do Judiciário. A objeção não é forte, porque os naturais desvios que, imputáveis à falibilidade humana, já alimentavam, durante os trabalhos preparatórios da Constituição americana, o ceticismo calvinista em relação aos riscos de facciosidade do parlamento, são inerentes a todas as instituiçōes, por acabadas e perfeitas que se considerem. Mas, se escusa reforço à resposta, é sobremodo importante notar que o Conselho não julga causa alguma, nem dispõe de nenhuma atribuição, de nenhuma competência, cujo exercício fosse capaz de interferir no desempenho da função típica do Judiciário, a jurisdicional. Pesa-lhe, antes, abrangente dever constitucional de "zelar pela autonomia" do Poder (art. 103-B, $\mathbb{S} 4^{\circ}$, inc. I). E não seria lógico nem sensato levantar suspeitas de que, sem atribuiçāo jurisdicional, possa comprometer independência que jamais se negou a órgãos jurisdicionais integrados por juízes cuja nomeação compete ao Poder Executivo, com ou sem colaboração do Legislativo. Será caso, no entanto, de indagar se tal risco não adviria da própria natureza das competências destinadas ao Conselho, enquanto órgão nacional de controle da atuação administrativa e financeira do Poder Judiciário e do cumprimento dos deveres funcionais dos magistrados. Aqui, a dúvida é de menor tomo. Com auxílio dos tribunais de contas, o Legislativo sempre deteve o poder superior de fiscalização dos órgãos jurisdicionais quanto às atividades de ordem orçamentária, financeira e contábil (arts. 70 e 71 da Constituição da República), sem que esse, sim, autêntico controle externo

Teoria geral do processo. 21. ed. São Paulo: Malheiros, p. 172. 
do Judiciário fosse tido, alguma feita e com seriedade, por incompatível com o sistema da separação e independência dos Poderes, senão como peça da mecânica dos freios e contrapesos. E esse quadro propõe ainda um dilema: ou o poder de controle intermediário da atuação administrativa e financeira do Judiciário, atribuído ao Conselho Nacional de Justiça, não afronta a independência do Poder, ou será forçoso admitir que o Judiciário nunca foi, entre nós, Poder independente! Igual coisa pode dizer-se de imediato sobre a competência de controle do cumprimento dos deveres funcionais dos juízes. Ou a atribuição em si, a este ou àquele órgão, não trinca nem devora a independência do Poder, ou se há de confessar que este nunca tenha sido verdadeiramente autônomo ou independente. A outorga dessa particular competência ao Conselho não instaura, como novíssima das novidades, o regime censório interno, a que, sob a ação das corregedorias, sempre estiveram sujeitos, em especial, os magistrados dos graus inferiores, senão que, suprindo uma das mais notórias deficiências orgânicas do Poder, capacita a entidade a exercer essa mesma competência disciplinar, agora no plano nacional, sobre todos os juízes hierarquicamente situados abaixo desta Suprema Corte. ${ }^{34}$

Como se percebe sem grandes ginásticas de dialética, deu-se apenas dimensão nacional a um poder funcional necessário a todos os ramos do governo, e cujo exercício atém-se, como não podia deixar de ser, às prescriçōes constitucionais e às normas subalternas da Lei Orgânica da Magistratura e do futuro Estatuto, emanadas todas do Poder Legislativo, segundo os princípios e as regras fundamentais da independência e harmonia dos Poderes.

5. E é o momento de recobrar a questão crucial da causa e que está em saber se, de qualquer outro modo, direto ou indireto, em maior ou menor grau, a criação, a composição e as atribuiçōes do Conselho põem em risco, mínimo que seja, o exercício das funçōes jurisdicionais, enquanto razão mesma da existência do Poder Judiciário. É que, como o sabe toda a gente, as exigências e as preocupaçōes de tutela cabal da sua autonomia se radicam na necessidade de preservação das garantias indispensáveis ao desempenho imparcial daquelas funções. No dizer de MAURO CAPPELLETTI: "a independência dos juízes frente ao executivo, longe de representar um valor fim em si mesmo, não é ela própria senão um valor instrumental. É difícil não compartilhar da opinião de Giovani Pugliese - que é, aliás, também a da nossa Corte Constitucional - quando afirma, exatamente, que a independência não é senão o meio dirigido a salvaguardar outro valor - conexo certamente, mas diverso e bem mais importante do que o primeiro - ou seja, a

\footnotetext{
34 Os ministros do Supremo, órgāo máximo do Judiciário brasileiro e guardiāo último da Constituiçāo Federal, nāo estāo, nem poderiam estar, como é óbvio, sujeitos ao poder disciplinar do Conselho, cujos atos e decisões, sempre de natureza administrativa, é que são passíveis de controle jurisdicional desta Corte (art. 102, inciso I, letra " $r$ ", introduzido pela Emenda). O que dispōe a Emenda, no art. 103-B, $\$ 4^{\circ}$, nāo os apanha, como se percebe sem muito esforço. SÉRGIO BERMUDES achou necessário dissipar dúvidas a respeito, as quais, aliás, nem seriam razoáveis: "Excluem-se da incidência desse $\$ 4^{\circ}$ apenas os ministros do Supremo Tribunal Federal... A submissão dos ministros do Supremo Tribunal Federal ao Conselho Nacional de Justiça perturbaria a ordem constitucional, inclusive pela possibilidade de repercutir, de algum modo, nos julgamentos do órgão supremo do Poder Judiciário" (A reforma do poder judiciário pela emenda constitucional $n^{\circ} 45$. Rio de Janeiro: Forense, 2005, p. 137). Sobre o ponto, cf. ainda infra, $n^{\circ} 12$.
} 
imparcialidade do juiz. O valor 'final' - a 'essência' ou a 'natureza', por assim dizer - da função judiciária é, portanto, que a decisão seja tomada por um terceiro imparcial, tertius super partes, depois que as partes tenham tido a possibilidade de apresentar e defender o seu caso (...)". ${ }^{35}$

É o que reconhece o ex-magistrado LUIS FLÁVIO GOMES, em referência à obra de IBAÑEZ: "concebemos a independência judicial desse modo, não como um fim em si mesmo, senão como um meio, um conceito instrumental em relação à imparcialidade, a serviço da idéia de que o juiz deve sempre atuar como terceiro na composição dos interesses em conflito, com a lei como ponto de referência indiscutível". ${ }^{36}$

Está nisto, no valor político supremo da imparcialidade dos juízes e tribunais, o critério decisivo da estima da compatibilidade do Conselho Nacional de Justiça com todas as provisões constitucionais de um Judiciário independente. E, de tal ângulo, não vejo em que este sofra com aquele. Como já referi, são duas, em suma, as ordens de atribuições conferidas ao Conselho pela Emenda Constitucional no 45/2004: (a) o controle da atividade administrativa e financeira do Judiciário, e (b) o controle ético-disciplinar de seus membros. A primeira não atinge o autogoverno do Judiciário. Da totalidade das competências privativas dos tribunais, objeto do disposto no art. 96 da Constituição da República, nenhuma lhes foi castrada a esses órgãos, que continuarão a exercê-las todas com plenitude e exclusividade, elaborando os regimentos internos, elegendo os corpos diretivos, organizando as secretarias e serviços auxiliares, concedendo licenças, férias e outros afastamentos a seus membros, provendo os cargos de juiz de carreira, assim como os necessários à administração da justiça, etc., sem terem perdido o poder de elaborar e encaminhar as respectivas propostas orçamentárias. O que tampouco deve esquecido é que também nesse campo se manifesta o caráter não absoluto da independência constitucional do Poder. Afora as limitações concernentes à elaboração dos orçamentos, a criação ou extinção dos tribunais, a alteração do número de seus membros, a modificação da organização e da divisão judiciárias, bem como a criação de cargos e a remuneração dos serviços auxiliares e dos juízos vinculados ao Supremo Tribunal Federal, aos Tribunais Superiores e aos Tribunais de Justiça também dependem da aprovação do Poder Legislativo (art. 96, inc. II), o que demonstra, mais uma vez, que: "as garantias do art. 96 da Constituição visam essencialmente a estabelecer a independência do Poder Judiciário em relação aos demais Poderes. Mas se é absoluta essa independência no que respeita ao desempenho de suas funçōes, não se pode dizer o mesmo no tocante à organização do Poder Judiciário, a qual depende freqüentemente do Poder Executivo ou do Legislativo, quando não de ambos". ${ }^{3-}$

\footnotetext{
35 Juízes irresponsáveis? Traduçāo de Carlos Alberto Álvaro de Oliveira. Porto Alegre: Sergio Antonio Fabris, 1989, p. 32

36 A dimensāo da magistratura no estado constitucional e democrático de direito. São Paulo: Revista dos Tribunais, 1997, p. 42.

3:- ARAÚJO CINTRA, ANTÔNIO CARLOS DE, GRINOVER, ADA PELLEGRINI e DINAMARCO, CÂNDIDO RANGEL. Ob. e loc. cit.
} 
De modo que, sem profanar os limites constitucionais da independência do Judiciário, agiu dentro de sua competência reformadora o poder constituinte derivado, ao outorgar ao Conselho Nacional de Justiça o proeminente papel de fiscal das atividades administrativa e financeira daquele Poder. A bem da verdade, mais que encargo de controle, o Conselho recebeu aí uma alta função política de aprimoramento do autogoverno do Judiciário, cujas estruturas burocráticas dispersas inviabilizam o esboço de uma estratégia político-institucional de âmbito nacional. São antigos os anseios da sociedade pela instituição de um órgão superior, capaz de formular diagnósticos, tecer críticas construtivas e elaborar programas que, nos limites de suas responsabilidades constitucionais, dêem respostas dinâmicas e eficazes aos múltiplos problemas comuns em que se desdobra a crise do Poder.

Como bem acentuou JOSÉ EDUARDO FARIA: “[...] como o Judiciário tem diferentes braços especializados organizados em diferentes instâncias, é natural que cada um deles e cada uma delas sinta-se tentado a definir seu próprio programa de ação, o que, obviamente, torna de fundamental importância a criação de um órgão representativo de todos esses braços e instâncias capazes de atuar numa dimensão de política-domínio, responsabilizando-se pela uniformização dos diferentes programas 'parcialmente contraditórios' e 'parcialmente compatíveis' sob a forma de uma estratégia global da instituição." 38 Ao Conselho atribuiu-se esse reclamado papel de órgāo formulador de uma indeclinável política judiciária nacional.

6. A segunda modalidade de atribuiçōes do Conselho diz respeito ao controle "do cumprimento dos deveres funcionais dos juizes" (art. 103-B, $\$ 4^{\circ}$ ). E tampouco parece-me hostil à imparcialidade jurisdicional. Representa expressiva conquista do Estado democrático de direito, a consciência de que mecanismos de responsabilização dos juízes por inobservância das obrigaçōes funcionais são também imprescindíveis à boa prestação jurisdicional. Na síntese feliz de JUAN MONTERO AROCA,${ }^{39}$ a responsabilidade judicial é a outra face da moeda da independência, a sua contrapartida. E a necessidade, que o Programa de Desenvolvimento da ONU $(P N U D)$ já enfatizou, ${ }^{40}$ de se coordenarem ambas essas exigências, põe-nos, como bem o percebeu o saudoso MAURO CAPPELLETTI, diante de "um problema de equilibrio entre o valor de garantia e instrumental da independência, externa e interna, dos juizes, e o outro valor moderno (mas também antigo, como se viu) do dever democrático de prestar contas". ${ }^{41} \mathrm{E}$ uma enorme dificuldade para se atingir tão sutil equilíbrio é fenômeno observado em toda a América Latina, como mostra WILLIAM PRILLAMAN. ${ }^{42}$

\footnotetext{
38 O poder judiciário no Brasil: paradoxos, desafios e alternativas. Brasília: Conselho da Justiça Federal, 1995, p. 71.

39 Independencia y responsabilidad del juez. Madrid: Civitas, 1990, p. 91.

4o Judicial independence in transitional country. United Nations Development Programme. Oslo: Governance Centre, 2003, p. 27.

4) Ob. cit., p. 33 .

t2 Ob. cit., p. 19.
} 
Entre nós, é coisa notória que os atuais instrumentos orgânicos de controle ético-disciplinar dos juízes, porque praticamente circunscritos às corregedorias, não são de todo eficientes, sobretudo nos graus superiores de jurisdição, como já o admitiram com louvável sinceridade os próprios magistrados, em conhecido estudo de MARIA TEREZA SADEK.$^{43}$ Realidade algo semelhante encontra-se nos demais países latino-americanos. ${ }^{44}$ Perante esse quadro de relativa inoperância dos órgãos internos a que se confinava o controle dos deveres funcionais dos magistrados, não havia nem há por onde deixar de curvar-se ao cautério de NICOLÒ TROCKER: "o privilégio da substancial irresponsabilidade do magistrado não pode constituir o preço que a coletividade é chamada a pagar, em troca da independência dos seus juízes". ${ }^{45}$ Nem ao aviso de LIMA LOPES: "o Poder Judiciário não pode ser independente, no sentido de irresponsável, ou não prestar contas à sociedade, aos cidadãos, no que diz respeito à máquina judicial. Se quisermos livrar os juízes do controle dos cartórios, dos lobbies, das pressōes corporativas, é preciso colocá-los ombreados com a cidadania". ${ }^{46} \mathrm{Tem}$-se, portanto, de reconhecer, como imperativo do regime republicano e da própria inteireza e serventia da função, a necessidade de convívio permanente entre a independência jurisdicional e instrumentos de responsabilização dos juízes que não sejam apenas formais, mas que cumpram, com efetividade, o elevado papel que se lhes predica. Para isso, é preciso, com reta consciência e grandeza de espírito, desvestirem-se os juízes de preconceitos corporativos e outras posturas irracionais, como a que vê na imunidade absoluta e no máximo isolamento do Poder Judiciário condiçōes sine qua non para a subsistência de sua imparcialidade. Como pondera o jurista norte-americano OWEN FISS: "It is simply not true that the more insularity the better, for a judiciary that is insulated from the popularly controlled institutions of government - the legislative and the executive branches - has the power to interfere with the actions or decisions of those institutions, and thus has the power to frustrate the will of the people. [...] We are thereby confronted with a dilemma. Independence is assumed to be one of the cardinal virtues of the judiciary, but it must be acknowledged that too much independence may be a bad thing. We want to insulate the judiciary from the more popularly controlled institutions, but should recognize at the same time some elements of political control should remain." 47

("Simplesmente nāo é verdade que, quanto maior o isolamento, melhor, porque um Judiciário que está isolado das instituiçōes governamentais sujeitas a con-

43 Ob. cit., esp. p. 118-126.

t4 Ob. cit., p. 21.

45 La responsabilitá del giudice. Rivista trimestrale di diritto e procedura civile. 1982, p. 1.285, apud. CAPPELLETTI, Mauro. Ob. cit., p. 33.

* LIMA LOPES, José Reinaldo de. Crise da norma jurídica e reforma do judiciário. In: FARIA, José Eduardo (Org.). Direitos humanos, direitos sociais e justiça. São Paulo: Malheiros, 2002, p. 76.

4. The right degree of independence. In: Transitions to democracy in Latin America: the role of judiciary, 1993, p. 56, apud PRILLAMAN, William. Ob. cit., p. 17. Há recente tradução desse ensaio de OWEN FISS no Brasil, na obra Um novo processo civil - estudos norte-americanos sobre jurisdição, constituição e sociedade. São Paulo: Revista dos Tribunais, 2004. 
trole popular - o Legislativo e o Executivo - tem o poder de interferir nas açōes ou decisões dessas instituições e, assim, o poder de frustrar a vontade popular. [...] Estamos, portanto, diante de um dilema. A independência é tida como uma das virtudes cardinais do Judiciário, mas deve-se reconhecer que muita independência pode ser uma coisa negativa. Nós queremos isolar o Judiciário das instituições sujeitas a maior controle popular, mas deveríamos admitir, ao mesmo tempo, que alguns elementos de controle político deveriam remanescer"). Longe, pois, de conspirar contra a independência judicial, a criação de um órgão com poderes de controle nacional dos deveres funcionais dos magistrados responde a uma imperfeição contingente do Poder, no contexto do sistema republicano de governo. Afinal, "regime republicano é regime de responsabilidade. Os agentes públicos respondem por seus atos". ${ }^{48} \mathrm{E}$ os mesmos riscos teóricos de desvios pontuais, que se invocam em nome de justas preocupaçōes, esses já existiam no estado precedente de coisas, onde podiam errar, e decerto em alguns casos erraram, os órgãos corregedores. Nem embaraça a conclusāo, o fato de que tenham assento e voz, no Conselho, membros alheios ao corpo da magistratura. Bem pode ser que tal presença seja capaz de erradicar um dos mais evidentes males dos velhos organismos de controle, em qualquer país do mundo: o corporativismo, essa moléstia institucional que obscurece os procedimentos investigativos, debilita as medidas sancionatórias e desprestigia o Poder. Uma das mais graves degenerações suscetíveis de acometer os modernos aparatos judiciários é, segundo a observação incontestável de MAURO CAPPELLETTI, a "monopolização da responsabilidade disciplinar em mãos da própria magistratura e, conseqüentemente, na sua degeneração em instrumento de controle puramente corporativo, isolado da sociedade". O perigo com que se defronta é o “'isolamento' da magistratura, a sua transformação num corps séparé, destacado do resto do sistema estatal e da sociedade em geral". ${ }^{49}$ Igual opinião sustenta WILLIAM PRILLAMAN: "[...] an independent judiciary can degenerate not only into a politicized bureaucracy but also into an insular, unaccountable one".${ }^{50} \mathrm{E}$ desse perigo não se isenta nem desvencilha o país. Do exame comparativo de diversos sistemas judiciários, conclui LIMA LOPES que "o Brasil é, nesta série de exemplos, um caso único, como se vê, em que independência e autonomia estão mais próximas do sistema do antigo regime de patrimonialidade dos cargos, de exclusivismo corporativo até, do que de democracia propriamente dita. Aqui talvez se esteja confundindo, no debate atual, autonomia do Poder Judiciário com capacidade de isolamento. É da maior importância, hoje, não confundir autonomia e independência do Judiciário com seu isolamento social". ${ }^{51}$ A presença, aliás minoritária e com mandatos pessoais de duraçāo limitada, de membros não pertencentes aos quadros da magistratura, aparece como um dos remédios contra o mal. A respeito, é bom ouvir de

\footnotetext{
48 ATALIBA, Geraldo. República e constituição. 2. ed. São Paulo: Malheiros, 2001, p. 65.

49 Ob cit., p. 73 e 75. Mesma opiniāo foi expressa pelo autor no ensaio Who watches the watchmen? In: American Journal of Comparative Law, v. 31, 1983, p. 48-50.

50 Ob. cit., p. 16.

51 LIMA LOPES, José Reinaldo de. Ob. cit., p. 80.
} 
novo a MAURO CAPPELLETTI: “a arma talvez mais freqüentemente utilizada para combater essa degeneração consiste em incluir membros 'laicos' nos órgãos investidos do poder disciplinar, mais uma vez na tentativa de encontrar razoável equilíbrio entre o valor da independência e o de certo grau de uniāo, que em verdade nunca deveria faltar completamente, do judiciário com o resto do body politic". ${ }^{52}$ Uma persistente conexão entre o Judiciário e o corpo político é, ademais, importante fator de legitimação social e democrática - não falo aqui do mito do déficit de legitimação democrática, mas de outra coisa - que não deve subestimado por arrogância da magistratura, pois, como nota BOAVENTURA SOUSA SANTOS, "a democratização da administração da justiça é uma dimensão fundamental da democratizaçāo da vida social, económica e política", cuja abertura deve, como ideal, incluir "o maior envolvimento e participação dos cidadãos, individualmente ou em grupos organizados, na administração da justiça". ${ }^{53}$

De modo que, num juízo objetivo e sereno, como convém à matéria e ao interesse público, a composição do Conselho - cujo modelo não pode deixar de ser "pluralístico e democrático" 54 - estende uma ponte entre o Judiciário e a sociedade, de um lado permitindo oxigenação da estrutura burocrática do Poder e, de outro, respondendo às críticas severas, posto nem sempre de todo justas para com a instituição, que lhe vinham de fora e de dentro, como ecos da opinião pública. De fora, DALMO DE ABREU DALLARI pregava: “[...] é necessário estabelecer um sistema de controle. É oportuno lembrar aqui a atitude de Thomas Jefferson, que defendeu com firmeza a independência dos juízes e tribunais, mas admitiu que tinha medo do corporativismo dos magistrados, o que pode significar não só uma comunhão de interesses, mas também um relacionamento afetivo. Daí a conveniência de um órgão controlador, integrado, em sua maioria, por magistrados, mas também por profissionais de outras áreas juridicas, como se tem feito para compor bancas examinadoras de concursos de ingresso na magistratura. Não se pode esquecer que o Poder Judiciário exerce poder público, age em nome do povo, embora seus membros não sejam escolhidos por meio de eleição popular. Por isso é necessário um controle democrático de seu desempenho, que assegure a obediência às regras legais e a prevalência do interesse público, mantendo o requisito fundamental, que é a garantia da independência dos juízes". ${ }^{55}$ De dentro, o ilustre Min. CELSO DE MELLO era só mais sutil: "Estou cada vez mais convencido da necessidade de controle externo sobre o Poder Judiciário. Fiscalização e responsabilidade são princípios do modelo republicano. A fiscalização externa não compromete o princípio da separação dos Poderes. Ela não quer dizer que se vá exercer censura sobre o pensamento dos magistrados. A independência dos juízes deve ser preservada. Mas

\footnotetext{
Ob. cit., p. 75-76.

53. Pela mão de Alice: o social e o político na pós-modernidade. 9. ed. São Paulo: Cortez, 1995, p. 177.

it ZAFFARONI, Eugenio Raúl. Ob. cit., p. 130.

55 Juizes independentes, judiciário sob controle social. In: Revista da Associação dos Magistrados do Estado do Rio de Janeiro, ano 2, $n^{22} 8$, p. 33. Grifos nossos.
} 
ela não é uma finalidade em si própria. É preciso ter juizes independentes para se poder ter cidadāos livres." "O Judiciário só pode enfraquecer se seus membros falharem gravemente no desempenho das suas funçōes. Os magistrados devem se expor democraticamente à crítica social. Nenhum Poder da República está acima da Constituição, nem pode pretender que sua fisionomia institucional não possa ser redesenhada." ${ }^{7}$ " [...] entendo que a discussão em torno da fiscalização externa torna-se essencial até mesmo para conferir legitimidade político-social à atividade do magistrado e evitar que abusos funcionais, que situações de ilicitude que ocorrem lamentavelmente na intimidade dos corpos judiciários continuem a ocorrer. É preciso fiscalizar." 58

O real temor gerado pela presença de não-magistrados no Conselho Nacional de Justiça está em que sua fiscalização ético-disciplinar, num plano de superposição, transponha os horizontes constitucionais e legais, transformando-se em instrumento de dominação política da magistratura. Não se deve baratear tão válida preocupaçāo de que um controle arbitrário corrompa as condiçōes e garantias de imparcialidade dos juízes e, como tal, desnature a Jurisdição. Mas não se deve tampouco sobreestimá-la, nem ceder a puras fantasias, como se não dispusesse o sistema de mecanismos aptos de defesa, com força bastante para neutralizar riscos teóricos. Neste passo, vale a pena chamar a atenção para o fato de que a própria Emenda Constitucional no 45/2004 contém provisões adequadas a garantir que o exercício do poder disciplinar se paute por critérios de rigorosa legalidade. Relembre-se, ainda uma vez, de que a maioria qualificada de membros do Conselho é formada de juízes e, pois, de pessoas insuspeitas à magistratura, aprovadas e experimentadas no ofício de aplicar a lei. Donde é lícito crer que tal maioria constitua o primeiro elemento regulador da retidão e legitimidade do uso do poder de controle atribuído ao órgão. Acresça-se-lhe a circunstância, não menos significativa, de que a função de Ministro-Corregedor é destinada ao Ministro representante do Superior Tribunal de Justiça (art. 103-B, $\$ 5^{\circ}$ ). Mas até a minoria, composta por não-magistrados, é tida, sob vigorosa presunção hominis, por afeita às atividades jurisdicionais, não só no caso manifesto dos representantes do Ministério Público e da advocacia, senão também no dos dois cidadãos que, indicados pelo Legislativo, devam, à moda dos candidatos a esta Corte (art. 101 da Constituição da República), possuir "notável saber jurídico e reputação ilibada". Que outros requisitos se poderiam pedir aos membros não-magistrados, como garantia de vivência jurídica, de compromisso com a autonomia do Poder e de fidelidade à lei? Ao depois, a participação de juízes de hierarquia inferior em decisões disciplinares sobre atos de juizes de categoria superior não rompe nenhum princípio nem regra constitucional imutável, porque não encerra nem supōe atribuição de competência monocrática cujo exercício subverta relações hierárquicas.

\footnotetext{
36 Entrevista concedida ao jornal Folha de S. Paulo, em 11-4-99.

5. Entrevista concedida ao jornal Folha de S. Paulo, em 19-3-99.

58 Apud SADEK, Maria Tereza. Ob. cit., p. 132.
} 
É que o caso retrata apenas competência destinada a formar a vontade coletiva de órgão colegiado, ao qual é adjudicado o poder de decidir. A argüição da autora, aqui, nasce de erro de perspectiva, porque não atina com o fato de que a relação hierárquica, pressuposta ao poder de decidir, se estrutura entre o órgão superior, o Conselho, e o juiz subordinado, cuja conduta é objeto do julgamento, não entre este e o juiz ou juízes integrantes do Conselho, os quais só podem ser considerados de hierarquia inferior sob outro ponto de vista. A competência de decidir e o conteúdo da decisão são juridicamente imputados ao órgão, não a cada uma das pessoas que o compōem. A relação hierárquica correspondente forma-se no nível decisório (eficácia da decisão), entre órgão superior e magistrado que lhe está sujeito, o que nada tem a ver com o tipo de subordinação que se dá noutro plano, o dos degraus da carreira.

7. Entre os membros laicos, cuja previsão dá caráter heterogêneo à composição do Conselho Nacional de Justiça, constam dois representantes do Ministério Público e dois advogados, todos indicados pelos pares (art. 103-B, incs. XI e XII). Por mais que forcejasse, não encontrei nenhuma razão de índole constitucional que lhes pudera vetar a participaçāo no Conselho. Pressuposto agora que a instituição do Conselho, não apenas simboliza, mas também opera ligeira abertura das portas do Judiciário para que representantes da sociedade tomem parte no controle administrativo-financeiro e ético-disciplinar da atuação do Poder, robustecendo-lhe o caráter republicano e democrático, nada mais natural que os dois setores sociais, cujos misteres estão mais próximos das atividades profissionais da magistratura, a advocacia e o Ministério Público, integrem o Conselho responsável por esse mesmo controle. Não é à toa que ambas as profissões são objeto de normas da Constituição da República, no âmbito do capítulo reservado à disciplina das "funções essenciais à Justiça". De acordo com o art. 127, "o Ministério Público é instituição permanente, essencial à função jurisdicional do Estado". E o art. 133 reputa o advogado "indispensável à administração da justiça". Esses cânones nāo se limitam a refletir ou reafirmar, no mais alto escalão nomológico, certos truísmos ligados aos papéis da advocacia e do Ministério Público, como, v.g., que suas iniciativas técnicas desencadeiam o exercício da função jurisdicional, cuja inércia é garantia da imparcialidade que a caracteriza como monopólio e obrigação do Estado. Ou que, como órgãos dotados de capacidade postulatória, legitimem esse mesmo exercício, dando concreção a todos os princípios inerentes à cláusula do justo processo da lei (due process of law). Aqueles preceitos vão além, porque concebem e proclamam, como ingredientes da própria ordem jurídico-constitucional, a dignidade e a relevância da advocacia e do Ministério Público enquanto funçōes essenciais da Justiça, e cujos titulares são, como tais, merecedores de garantias, como a inviolabilidade relativa dos atos emanifestações emanados no exercício da profissão de advogado (art. 133), e as prerrogativas e vedações análogas às dos juízes, relativamente aos membros do Ministério Público (art. 128, $\$ 5^{\circ}$ ). Eis o fundamento da previsão de participação da Ordem dos Advogados em todas as fases do concurso de ingresso na carreira da magistratura (art. 93, I). 
Tudo isso comprova a decisiva responsabilidade que, ao lado da magistratura, pesa, já no plano constitucional originário, à advocacia e ao Ministério Público, quanto ao correto desenvolvimento da atividade estatal que, atribuída como função típica ao Poder Judiciário no quadro da separação dos poderes, constitui a própria razão de ser das três categorias profissionais. De modo que, pelo menos no nível teórico, e é esse o que sobreleva na causa, os rumos dos interesses institucionais não podem deixar de convergir para o mesmo propósito político: $o$ aprimoramento da atividade jurisdicional.

É, pois, compreensível e conforme, não contrário, aos princípios que, presumindo-se ambas as instituiçōes aptas e interessadas em oferecer contribuições valiosas ao aperfeiçoamento da função jurisdicional, a advocacia e o Ministério Público ganhem posto e dever de cooperação no seio do órgão agora predestinado ao controle nacional da atuação administrativo-financeira e ético-funcional do Judiciário.

Por fim, se o instituto que atende pelo nome de quinto constitucional, enquanto integração de membros não pertencentes à carreira da magistratura em órgãos jurisdicionais, encarregados do exercício da função típica do Judiciário, não ofende o princípio da separação e independência dos Poderes, então não pode ofendê-la a fortiori a mera incorporação de terceiros em órgão judiciário carente de competência jurisdicional.

8. Terão sido estas, desconfio, algumas das razōes que levaram o Min. SEPÚLVEDA PERTENCE, no bojo dos votos proferidos no julgamento das ADI $\mathbf{n}^{\circ}$ 98 e $\mathbf{n}^{\circ} 183$, a sustentar que eventual presença de representante da Ordem dos Advogados do Brasil, em conselho dotado de atribuiçōes similares às do órgão criado pela Emenda Constitucional n" 45/2004, poderia amparar-se na "definiçãa constitucional da advocacia como função essencial à Justiça". E, em entrevista à imprensa, a deixar clara sua posiçāo favorável à "abertura para integrantes da Ordem dos Advogados do Brasil (OAB) e do Ministério Público", de conselho destinado a "formular políticas e uniformizar critérios administrativos para o setor". ${ }^{59}$

E por coincidência, mais ou menos na mesma época, também o Min. CARLOS VELLOSO se pronunciou publicamente pela criação de um Conselho Nacional da Magistratura que contasse com a participação de representantes "do Ministério Público, além de membros da OAB e outras instituiçōes idôneas". ${ }^{60}$ Não fora impróprio, eu até diria que já não devem agora sentir-se lá confortáveis os advogados e os membros do Ministério Público, porque, com c assento dos seus representantes no Conselho, se despem da cômoda posição de observadores críticos, para se converterem em co-responsáveis formais pelos rumos do Judiciário. 9. A autora deduz ainda outro argumento que se prestaria a demonstrar a inconstitucionalidade do Conselho, cuja instituição violaria o pacto federativo, "ao submeter o poder judiciá-

9 Entrevista concedida ao Jornal de Brasília, em 22-9-1995.

60 Entrevista concedida ao Jornal do Brasil, em 26-12-1994. 
rio dos estados membros à supervisão administrativa e disciplinar do conselho nacional de justiça" (fls. 30).

Também aqui não lhe dou razão. O pacto federativo não se desenha nem expressa, em relação ao Poder Judiciário, de forma normativa idêntica à que atua sobre os demais Poderes da República. Porque a Jurisdição, enquanto manifestação da unidade do poder soberano do Estado, tampouco pode deixar de ser una e indivisível, é doutrina assente que o Poder Judiciário tem caráter nacional, não existindo, senāo por metáforas e metonímias, "Judiciários estaduais" ao lado de um "Judiciário federal". A divisão da estrutura judiciária brasileira, sob tradicional, mas equívoca denominação, em Justiças, é só o resultado da repartição racional do trabalho da mesma natureza entre distintos órgãos jurisdicionais. O fenômeno é corriqueiro, de distribuição de competências pela malha de órgãos especializados, que, não obstante portadores de esferas próprias de atribuições jurisdicionais e administrativas, integram um único e mesmo Poder. Nesse sentido fala-se em Justiça Federal e Estadual, tal como se fala em Justiça Comum, Militar, Trabalhista, Eleitoral, etc., sem que com essa nomenclatura ambígua se enganem hoje os operadores jurídicos. Na verdade, desde JOĀO MENDES JÚNIOR, cuja opiniāo foi recordada por CASTRO NUNES," sabe-se que: "O Poder Judiciário, delegação da soberania nacional, implica a idéia de unidade e totalidade da fôrça, que sāo as notas características da idéia de soberania. O Poder Judiciário, em suma, quer pelos juizes da União, quer pelos juízes dos Estados, aplica leis nacionais para garantir os direitos individuais; o Poder Judiciário não é federal, nem estadual, é eminentemente nacional, quer se manifestando nas jurisdições estaduais, quer se aplicando ao cível, quer se aplicando ao crime, quer decidindo em superior, quer decidindo em inferior instância." ${ }^{62}$ Desenvolvendo a idéia, asseveram ANTONIO CARLOS DE ARAÚJO CINTRA, ADA PELLEGRINI GRINOVER e CÂNDIDO RANGEL DINAMARCO: "O Poder Judiciário é uno, assim como una é a sua funçāo precípua - a jurisdição - por apresentar sempre o mesmo conteúdo e a mesma finalidade. Por outro lado, a eficácia espacial da lei a ser aplicada pelo Judiciário deve coincidir em princípio com os limites espaciais da competência deste, em obediência ao princípio una lex, una jurisdictio. Daí decorre a unidade funcional do Poder Judiciário. É tradicional a assertiva, na doutrina pátria, de que o Poder Judiciário não é federal nem estadual, mas nacional. É um único e mesmo poder que se positiva através de vários órgãos estatais - estes, sim, federais e estaduais. [...] fala a Constituição das diversas Justiças, através das quais se exercerá a função jurisdicional. A jurisdiçāo é uma só, ela não é nem federal nem estadual: como expressão do poder estatal, que é uno, ela é eminentemente nacional e não comporta divisōes. No entanto, para a divisão racional do trabalho é conveniente que se instituam organismos distintos, outorgando-se a cada um deles um setor da grande 'massa de causas' que precisam ser processadas no país. Atende-se, para essa distribuição de competência,

\footnotetext{
ni Teoria e prática do poder judiciário. Rio de Janeiro: Forense, 1943, p. 77.

.2 ALMEIDA JÚNIOR, João Mendes de. Direito judiciário brasileiro. 5. ed. Rio de Janeiro: Freitas Bastos, 1960, p. 47. Grifos do original.
} 
a critérios de diversas ordens: às vezes, é a natureza da relaçāo jurídica material controvertida que irá determinar a atribuição de dados processos a dada Justiça; outras, é a qualidade das pessoas figurantes como partes; mas é invariavelmente o interesse público que inspira tudo isso (o Estado faz a divisão das Justiças, com vistas à melhor atuação da função jurisdicional.)"63

Negar a unicidade do Poder Judiciário importaria desconhecer o unitário tratamento orgânico que, em termos gerais, lhe dá a Constituição da República. Uma única lei nacional, um único estatuto, rege todos os membros da magistratura, independentemente da qualidade e denominação da Justiça em que exerçam a função (Lei Complementar no 35, de 14-3-1979; art. 93, caput, da CF). A todos aplicamse as mesmas garantias e restrições, concebidas em defesa da independência e da imparcialidade. Códigos nacionais disciplinam o método de exercício da atividade jurisdicional, em substituição aos códigos de processo estaduais. Por força do sistema recursal, uma mesma causa pode tramitar da mais longínqua comarca do interior do país, até os tribunais de superposição, passando por órgãos judiciários das várias unidades federadas. E, para não alargar a enumeração de coisas tão conhecidas, relembre-se que a União retém a competência privativa para legislar sobre direito processual (art. 22, inc. I).

Nesse diagrama constitucional, nunca se ouviu sustentar que as particularidades concretas da organização da estrutura judiciária violassem o pacto federativo. E não se ouviu, porque perceptível sua natureza nacional e unitária, embora decomposta e ramificada, por exigências de racionalização, em múltiplos órgãos dotados de sedes e de âmbitos distintos de competência. Não se descobre, pois, sob esse ângulo, porque a instituição do Conselho Nacional de Justiça não se ajustaria à organização constitucional do Poder.

Não se quer com isso afirmar que o princípio federativo não tenha repercussão na fisionomia constitucional do Judiciário. Sua consideração mais evidente parece estar à raiz da norma que delega aos Estados-membros competência exclusiva para organizar sua Justiça, responsável pelo julgamento das causas respeitantes a cada unidade federada (art. 125). Toca-lhes, assim, definir a competência residual de seus tribunais, distribuí-la entre os vários órgãos de grau inferior, bem como administrá-la na forma prevista no art. 96, coisa que revela que a estrutura judiciária tem um dos braços situados nas Justiças estaduais. Mas a criação do Conselho Nacional de Justiça em nada altera esse quadro, nem desfigura doutro modo o pacto federativo.

Ademais, o Conselho reúne as características palpáveis de órgão federal, enquanto representativo do Estado unitário, formado pela associaçāo das unidades federadas, mas não de órgão da União.

O Conselho não é concebido nem estruturado como órgão da Uniāo, e, sim, do Poder Judiciário nacional, donde ser irrelevante que seu orçamento seja fede-

63 Ob. cit., p. 166 e 184. 
ral, pois a origem da fonte de custeio não transmuda a natureza nem a relação de pertinência do órgão no plano da separação dos Poderes, que é o plano onde se situa o critério de sua taxinomia, que nada tem com outro plano classificatório, o das unidades da federação. A inicial, aqui, incide noutro erro de ótica, pois não vê o plano lógico em que está o critério de divisão dos órgāos do mesmo Poder, só enxergando o que discerne entre as entidades elementares da Grifos do original. federação. E é tão impróprio quanto supor que o Supremo Tribunal Federal e o Superior Tribunal de Justiça, por exemplo, não pudessem julgar recursos interpostos em causas da competência de órgāos jurisdicionais estaduais, ou de interesse de municípios, porque o custeio de ambos corre à conta do orçamento da União.

Daí não ser lícito estabelecer comparações do Conselho com os Executivos e Legislativos estaduais e municipais, porque estes não constituem Poderes nacionais, senão que se situam, definem e qualificam dentro das respectivas camadas da federação. E tampouco se pode imaginar, como pretende a inicial, que haveria supervisão administrativa, orçamentária, financeira e disciplinar dos órgãos judiciários estaduais por órgão da Uniāo. O Conselho, repita-se, não é órgão da União. Sua composição reverencia e contempla as duas esferas federativas dotadas de Justiças, a União e os Estados-membros, os quais contam ali com representantes das respectivas magistraturas (art. 103-B, incs. I a IX). Além disso, a indicação de um cidadão pelo Senado Federal exprime de certa maneira, senão a vontade, pelo menos forma indireta de participação dos Estados (art. 103-B, inc. XIII). Não vejo, pois, como cogitar de violação ao princípio federativo. Não é, como tentei demonstrar, imutável o conteúdo concreto da forma federativa. As relações de subordinação vigentes na estrutura do Judiciário, dado seu caráter nacional, como o reconhece a autora (item 51 da inicial), podem ser ampliadas e desdobradas pelo constituinte reformador, desde que tal reconfiguração não rompa o núcleo essencial das atribuiçōes do Poder em favor de outro. E foram redefinidas pela Emenda $n^{\underline{0}} 45$, sem usurpação de atribuiçōes por outro Poder, nem sacrifício da independência. A redução das autonomias internas, atribuídas a cada tribunal, não contradiz, sob nenhum aspecto, o sistema de separação e independência dos Poderes. A Corte cansou-se de proclamar que não são absolutas nem plenas as autonomias estaduais, circunscritas pela Constituição (art. 25), porque, se o fossem, seriam soberanias. E o Conselho não tem competência para organizar nem reorganizar as Justiças estaduais.

E é só órgāo que ocupa, na estrutura do Poder Judiciário, posição hierárquica superior à do Conselho da Justiça Federal e do Conselho Superior da Justiça do Trabalho, no sentido de que tem competência para rever-lhes os atos deste e daquele. Ora, está nisso o princípio capaz de resolver, em concreto, os conflitos aparentes de competência.

Por outro lado, a competência do Conselho para expedir atos regulamentares destina-se, por definição mesma de regulamento heterônomo, a fixar diretrizes para execução dos seus próprios atos, praticados nos limites de seus poderes 
constitucionais, como consta, aliás, do art. 103-B, $\$ 4^{\circ}$, I, onde se lê: "no âmbito de sua competência". A mesma coisa é de dizer-se a respeito do poder de iniciativa de propostas ao Congresso Nacional (art. 103-B, $\$ 4^{\circ}$, inc. VII).

Como consectário do princípio da unidade do Judiciário como Poder nacional, o Conselho recebeu ainda competência de reexame dos atos administrativos dos órgão judiciais inferiores, ou seja, o poder de controle interno da constitucionalidade e legitimidade desses atos. Ora, tal competência em nada conflita com as competências de controle exterior e posterior, atribuídas ao Legislativo e aos tribunais de contas. E o argumento vale para todos os atos de autogoverno, cujo poder não é subtraído, mas cujo exercício é submetido a processo de aperfeiçoamento mediante revisão eventual de órgão superior.

E, por fechar, neste tópico, o conjunto de respostas aos argumentos pontuais da demandante, nada mais insuspeito e apropriado do que transcrever opinião do então juiz LUIS FLÁVIO GOMES, em monografia de cerrada crítica a propostas de composição semelhante à do Conselho:

"O que está faltando na estrutura do Poder Judiciário brasileiro é a criação de um Conselho Nacional de Magistratura, que deve encarregar-se, precipuamente, de duas tarefas: do controle disciplinar de todos os juízes do país (esse controle seria originário em relação aos juízes de tribunais e em grau de recurso em relação aos juízes de primeiro grau), bem como da qualidade do juiz e do serviço prestado por todos os órgãos jurisdicionais. Seria ainda da sua competência a supervisão dos atos administrativos praticados pelos Tribunais bem como os de gestão orçamentária. Por ser um órgão idealizado para unificar a política judicial em todo país, é evidente que ainda lhe caberia encarregar-se da atividade correicional (fiscalização), sem prejuízo da exercida pelos Órgãos censórios já existentes nos vários setores da Justiça;

\section{[...]}

O Judiciário necessita de um órgão nacional de controle, que receba as reclamaçōes contra as atividades administrativas dos juizes e tribunais, assim como contra a qualidade do serviço judicial prestado, excluindo-se a estrita atividade jurisdicional que já está sujeita ao controle recursal. Os Tribunais devem controlar os juízes e o Conselho Nacional deve controlar diretamente os Tribunais e indiretamente todos os juízes, mas sempre no que diz respeito ao âmbito administrativo e disciplinar.

\section{[...]}

O que desejamos é um eficiente, criterioso e sobretudo transparente controle interno, de responsabilidade das corregedorias e tribunais assim como do Conselho Nacional. Se uma questão disciplinar de um juiz não encontra um justo equacionamento nos tribunais, que continuarão nor- 
malmente com sua atividade censória, será possível corrigir eventualmente falha perante o Conselho Nacional da Magistratura." 64

É antiga, aliás, em nosso sistema político-constitucional, a existência de órgãos federais a que se comete o papel de representar, arbitrar ou proteger os mais insignes interesses das unidades federadas, como é o caso do Senado (art. 46) e, até, desta Suprema Corte, com competência para o julgamento de conflitos que envolvam a "União e os Estados, a União e o Distrito Federal, ou entre uns e outros" (art. 102 , inc. I, "f").

A esse paradigma pode também reconduzir-se a instituição do Conselho, que, sob a rubrica das atribuições inerentes ao poder de controle da atuação administrativa e financeira do Judiciário (art. 103-B, $\$ 4^{\circ}$ ), assume o dever jurídico de diagnosticar problemas, planejar políticas e formular projetos, com vistas ao aprimoramento da organização judiciária e da prestação jurisdicional, em todos os níveis, como exigência da própria feição difusa da estrutura do Poder nas teias do pacto federativo. Como já acentuamos, somente um órgão de dimensão nacional e de competências centralizadas pode, sob tais aspectos, responder aos desafios da modernidade e às deficiências oriundas de visōes e práticas fragmentárias na administração do Poder.

O Conselho não anula, antes reafirma o princípio federativo.

10. A autora invoca ainda, em socorro de sua pretensão, algumas decisões da Corte em açōes diretas de inconstitucionalidade dirigidas à criação de conselhos estaduais de "controle externo" dos órgãos judiciários. De fato, chamado a avaliar a legitimidade constitucional de órgãos desse tipo, rejeitou-a sempre o Supremo Tribunal Federal, cuja invariável jurisprudência ao propósito consolidou-se na súmula 649 ("é inconstitucional a criação, por Constituição Estadual, de órgão de controle administrativo do Poder Judiciário do qual participem representantes de outros Poderes ou entidades").

Análise cuidadosa e, sobretudo, desinteressada mostra, todavia, que os precedentes se não ajustam nem aplicam ao caso. Em todos eles, era substancialmente diversa a situação posta ao julgamento da Corte. Em primeiro lugar, os conselhos criados por leis dos Estados da Paraíba, do Mato Grosso, de Sergipe, do Ceará e do Pará, objetos daqueles precedentes, figuravam autênticos órgãos externos ao Poder Judiciário, concebidos e disciplinados em posiçōes marginais à sua estrutura orgânico-burocrática.

Aliás, no caso decidido na ADI n 197, o art. 115 da Constituição do Estado de Sergipe preceituava, literalmente, que o conselho era "órgão de controle externo", e era-o em substância. Nenhuma das composições desses colegiados contava tampouco com presença majoritária de membros pertencentes às magistraturas

of A questão do controle externo do poder judiciário. Sāo Paulo: Revista dos Tribunais, 1993, p. 36, 37 e 38. 
estaduais. A representação dos juízes era ali, em todos os conselhos, apenas equiparada, quando não inferior ao número de membros advindos doutros setores sociais (cf. ADI $n^{\circ}$ 197, Rel. Min. OCTAVIO GALLOTTI, DJ de 25-5-1990; ADI $n^{\circ}$ 251, Rel. Min. ALDIR PASSARINHO, DJ de 2-4-1993; ADI nº 135, Rel. Min. OCTAVIO GALLOTTI, $D J$ de 15-8-1997; ADI no 98, Rel. Min. SEPÚlVEDA PERTENCE, $D J$ de 31-10-1997, ADI n 137, Rel. Min. MOREIRA ALVES, $D J$ de 3-10-1997).

Ora, não é esse o caso do Conselho Nacional de Justiça, que se define como órgāo interno do Judiciário e, em sua formação, apresenta maioria qualificada (três quintos) de membros da magistratura (arts. 92, 1-A e 103-B). Desses caracteres vem-lhe a natureza de órgão de controle interno, conduzido pelo próprio Judiciário, conquanto democratizado na composição por meio da participação minoritária de representantes das áreas profissionais afins.

Os conselhos criados pelos Estados da Paraíba, Mato Grosso e Pará compunham-nos, ainda, membros originais do Legislativo estadual (deputados), cuja presença não deixava nenhuma dúvida quanto à forma de interferência direta doutro Poder.

No Conselho Nacional de Justiça, dois dos quinze membros são apenas indicados pelo Poder Legislativo, mas escollhidos fora de seus quadros de agentes e políticos, dentre os cidadāos, sem nenhum vestígio de representação nem de interferência orgânica. É, pois, notável a distância que medeia entre uma coisa e outra.

Ao depois, e está aqui verdade jurídica que se deve antecipar e proclamar com toda a clareza, os Estados-membros carecem de competência constitucional para instituir conselhos, internos ou externos, destinados a controle de atividade administrativa, financeira ou disciplinar das respectivas Justiças, porque a autonomia necessária para o fazer seria incompatível com o regime jurídico-constitucional do Poder Judiciário, cuja unidade reflete a da soberania nacional.

O Poder Judiciário é nacional e, nessa condição, rege-se por princípios unitários enunciados pela Constituição, a qual lhe predefine ainda toda a estrutura orgânica, sem prejuízo das competências que delega a cada um dos grandes ramos nela previstos. Seu funcionamento obedece, em todos os níveis, a leis processuais uniformes, editadas exclusivamente da União (art. 22, inc. I), e seus membros, os magistrados, assujeitam-se a um único regime jurídico-funcional (art. 93, caput).

De modo que eventual poder de criação de conselho estadual, ordenado ao controle administrativo-financeiro e disciplinar da divisão orgânica do Poder, atribuída com fisionomia uniforme às unidades federadas, violentaria a Constituição da República, porque lhe desfiguraria o regime unitário, ao supor competência de controles díspares da instituição, mediante órgãos estaduais, cuja diversidade e proliferação, isto, sim, meteriam em risco o pacto federativo.

Ora, tal vício de inconstitucionalidade, que já mareava a criação daqueles esdrúxulos órgãos estaduais, não guarda nenhuma pertinência com a hipótese. 
O Conselho Nacional de Justiça é órgão judiciário de âmbito nacional, com atribuiçōes para atuar de maneira unitária e estratégica sobre todas as estruturas orgânicas do Poder.

E colhe-se outro dado fundamental, que remarca e exaspera a profunda diferença entre aqueles precedentes e este caso. $O$ juízo de constitucionalidade das normas instituidoras dos conselhos fez-se, é óbvio, à luz da arquitetura que assumia o princípio da separação dos Poderes, à época, na Constituição da República, cujas regras, escusaria dizê-lo, não podiam ceder a leis subalternas. No mais profundo daqueles julgamentos, realizado na ADI $n^{\circ} \mathbf{9 8}$, relatada pelo Min. SEPÚLVEDA PERTENCE, foi reconhecido o fato, aqui já sobrelevado, de que:

"o princípio da separação e independência dos Poderes, malgrado constitua um dos signos distintivos fundamentais do Estado de Direito, não possui fórmula universal apriorística: a tripartição das funçōes estatais, entre três órgãos ou conjuntos diferenciados de órgãos, de um lado, e, tão importante quanto essa divisão funcional básica, o equilíbrio entre os poderes, mediante o jogo recíproco dos freios e contrapesos, presentes ambos em todas elas, apresentam-se em cada formulação positiva do princípio com distintos caracteres e proporções".

Sob tal luz, reputou-se que a criação do conselho estadual feria o postulado da tripartição dos Poderes, tal como desenhado pelo conjunto das normas constitucionais então vigentes.

Ora, a Emenda Constitucional no 45 , de 2004 , como produto do exercício de competência de que não dispunham nem dispõem os legisladores estaduais, operou, em resposta a uma singular necessidade sociopolítica de aperfeiçoamento do Judiciário, mais uma adaptação histórica na formulação positiva do princípio da separação, sem vulnerar-lhe a cláusula constitucional que proíbe a espoliação do cerne das atribuiçōes de um Poder em benefício de outro.

De modo que, por muitas e boas razões, não faz senso chamar este caso singular a contas com jurisprudência fundada noutros pressupostos constitucionais.

12. Ao cabo desta já longa argumentação sobre o objeto central da demanda, não tenho a mais tênue dúvida acerca da constitucionalidade das normas impugnadas. Devo confessar, porém, que, durante as esforçadas meditaçōes em que, sobre o tema, pus à prova a minha consciência, foi outra a razāo decisiva que, em remate, me seduziu e convenceu. E essa poderosa razāo diz com a regra do art. 102, inc. l, letra "r", que, introduzida, na Constituiçāo da República, pela Emenda Constitucional $n^{\circ} 45$, comete ao Supremo Tribunal Federal competência para, julgando ações, rever os atos praticados pelo Conselho Nacional de Justiça. Entre parênteses, noto que, ao tempo dos conselhos estaduais fulminados, não havia, aliás, no sistema, nem se justificava então que houvesse, nenhuma regra análoga, o que só reforça e agrava a radical impertinência dos precedentes invocados. 
Toda a estrutura lógico-jurídica do raciocínio do meu voto reduz-se à tentativa de, submetendo as normas da Emenda a estreito confronto com os princípios e regras que disciplinam e formam nosso sistema constitucional de separação de poderes, entendido nas perspectivas históricas e políticas de garantia da liberdade dos cidadāos contra os riscos institucionais do arbítrio e da prepotência, estimar se de algum modo não comprometiam, em última instância, a independência e a imparcialidade dos juízes, sem as quais ninguém pode realizar seu projeto histórico de convivência ética, nem se concebe Estado Democrático de Direito. Afinal, na sabatina obrigatória perante o Senado da República, já havia eu professado, não apenas a título de opiniāo de cidadão, senão também como firme convicção jurídica, que me opunha a toda proposta que pusesse em risco, direto ou indireto, próximo ou remoto, a garantia constitucional da independência e imparcialidade dos juízes, parecendo-me discutíveis todas as demais.

Dissiparam-se-me as hesitaçōes, quando, não podendo deixar de reconhecer, na ratio iuris da criaçāo do Conselho, a necessidade sociopolítica de um órgão nacional de controle das atividades judiciárias, visto como um de muitos instrumentos hábeis de reforma, já não experimentei nenhum receio racional de que sua estruturação, nos termos da Emenda, pudesse descambar, sem reparo nem remédio, para excessos esporádicos, mas passiveis de alimentar um clima de insuportável intimidação.

E já não experimentei, porque, para além de todos os mecanismos intrínsecos de resguardo da autonomia do Poder Judiciário, pressupostos alguns na Emenda e previstos outros na precedente ordem constitucional, a cujo respeito terá sido longo o discurso do meu voto, dei com a competência, atribuída a esta Corte, de revisão da constitucionalidade e da legitimidade dos atos do Conselho Nacional de Justiça. Está aí, nessa nobre responsabilidade que o constituinte derivado depositou nos ombros desta Casa, a garantia última e específica que a obriga, como órgão supremo do Poder Judiciário e guardião da Constituiçāo da República, a velar pela independência e imparcialidade dos juízes, aos quais já não sobra pretexto para se arrecearem de coisa alguma. Ninguém pode, aliás, alimentar nenhuma dúvida a respeito da posição constitucional de superioridade absoluta desta Corte, como órgão supremo do Judiciário e, como tal, armado de preeminência hierárquica sobre o Conselho, cujos atos e decisões, todos de natureza só administrativa, estão sujeitos a seu incontrastável controle jurisdicional. É o que logo notou a doutrina:

"Não bastasse a natureza do STF que, na estrutura do estado brasileiro, se põe acima de qualquer outro órgão administrativo ou judiciário, incumbido da guarda da Constituição (art. 102, caput), a Emenda entregou a ele o controle jurisdicional das decisões do Conselho Nacional de Justiça, conferindo-lhe competência para as açōes contra o órgão, mediante a adoção da alínea $r$ do inciso I do art. 102 da Constituição. 
Controlador do CNJ, não pode o Supremo ser, de nenhum modo, controlado por ele." ${ }^{\prime 5}$

E essa tranqüilidade final do meu convencimento mostrou ainda quão inútil era o alvitre de recorrer ao expediente técnico-jurídico de redução teleológica do alcance da Emenda, para, contornando dificuldades observadas alhures, ${ }^{66}$ sugerir interpretação que privasse os membros laicos do Conselho Nacional de Justiça de votar em matéria ético disciplinar dos magistrados.

O Supremo Tribunal Federal é o fiador da independência e imparcialidade dos juizes, em defesa da ordem jurídica e da liberdade dos cidadãos.

13. O último tópico da inicial impugna o disposto no art. 103-B, $\mathbb{\$} 4^{\circ}$, inc. III, que, também introduzido pela Emenda Constitucional no $45 / 2004$, se ressentiria de inconstitucionalidade formal, uma vez que a expressão "perda do cargo", contida no texto vindo da Câmara dos Deputados, foi suprimida ao texto aprovado no Senado Federal. $\mathrm{O}$ argumento é de que a norma decotada deveria ser submetida à reapreciaçāo da Câmara, em atenção ao art. $60, \$ 2^{\circ}$, da Constituição da República. A Advocacia-Geral da União e a Procuradoria-Geral da República invocaram, com muita propriedade, precedentes da Corte que demonstram não padecer de inconstitucionalidade o dispositivo. Este tribunal, deveras, já assentou:

"Proposta de emenda que, votada e aprovada na Câmara dos Deputados, sofreu alteração no Senado Federal, tendo sido promulgada sem que tivesse retornado à Casa iniciadora para nova votação quanto à parte objeto de modificação. Inexistência de ofensa ao art. $60, \mathbb{2} 2^{\mathrm{o}}$ da Constituição Federal no tocante à supressão, no Senado Federal, da expressão observado o disposto no $\mathbb{S} 6^{\circ}$ do art. 195 da Constituição Federal, que constava do texto aprovado pela Câmara dos Deputados em 2 (dois) turnos de votação, tendo em vista que essa alteração não importou em mudança substancial do sentido do texto (Precedente: ADC no 3, rel. Min. Nelson Jobim)" (ADI no 2.666, Rel. Min. ELLEN GRACIE, DJ de 6-12-2002).

"Quanto à alteração ocorrida na Câmara dos Deputados, relativa à supressão das palavras 'ou restabelecê-la', em seguida ao verbo 'reduzir', no $\$ 1^{\circ}$ do novo art. 75 , sem que a proposta tivesse retornado ao Senado para nova apreciação, tenho que esse aspecto não importou ofensa ao art. 60, $\$ 2^{\circ}$ da Carta Magna. Como amplamente debatido no julgamento liminar, a possibilidade de restabelecimento da alíquota original tinha caráter autônomo em relação à possibilidade da sua redução, não tendo a supressão

\footnotetext{
BERMUDES, Sérgio. A reforma do Judiciário pela emenda constitucional $n^{\circ} 45$. Ob. cit., p. 137.

¿6 Na Itália, onde a competência disciplinar do Consiglio Superiore della Magistratura é reservada a uma das suas Seções, foi preciso conferir a esse órgão, investido do poder censório, natureza jurisdicional, para viabilizar aos magistrados recurso às sessões reunidas da Cassaçāo, contra as decisões tomadas em tal matéria (cf. TORRENTE, Andrea. Verbete Consiglio Superiore della magistratura. In: Enciclopedia del diritto. Milano: Giuffrè, 1961, v. IX, p. 337, no 9).
} 
daquela importado em modificação substancial do sentido da norma aprovada e promulgada. O que importa, no caso, é que o texto promulgado foi devidamente aprovado por ambas as Casas, nos termos exigidos pelo $\$ 2^{\circ}$ do art. 60 da Constituição" (ADI n 2.031, Rel. Min. ELLEN GRACIE, $D J$ de 17-10-2003. Grifos nossos).

Dos mesmos autos consta decisão do então Relator, Min. OCTÁVIO GALLOTTI, à apreciação do pedido liminar, nestes termos:

"Aprovada a proposta pelo Senado Federal, foi ela, na Câmara, objeto, entre outros, de dois destaques de votação em separado (DVS's), de cuja aprovação redundaram as alterações mencionadas no relatório que precede este voto, a saber: a supressão do verbo 'restabelecer' no $\mathbb{} 2^{\circ}$, e a eliminação da oração final do $\$ 3^{\circ}$ do novo art. 75 do ADCT [...].

Foram, porém, destaques meramente supressivos, que não comprometem a aprovação do remanescente, solenemente promulgado em sessão conjunta das duas casas do Congresso. Essa a tradição do processo legislativo, que remonta à própria gênese do regime político em vigor, como se depreende do texto do art. 29 do Regimento Interno da Assembléia Nacional Constituinte de 1987/8, que vedou a apresentação de emendas, em segundo turno de votação, 'salvo as supressivas', claramente a indicar que não invalida, a aprovação destas, a subsistência do texto aprovado em primeiro turno" (ADI no 2.031, Rel. Min. OCTAVIO GALLOTTI, DJ de 28-6-2002. Grifos nossos).

No caso, a norma tachada de inconstitucional estabelece uma série de competências do Conselho Nacional de Justiça, cada uma das quais dotada de independência semasiológica e normativa. Amputada, no Senado, a expressão "perda do cargo", o texto residual, aprovado em ambas as Casas do Congresso, manteve intacto o sentido nomológico, dada sua perceptível autonomia semântica. É o que basta por repelir a argüição de ofensa ao art. $60, \$ 2^{\circ}$, da Constituição Federal.

De todo modo, como reconhece a própria autora, a inclusão do poder de ordenar perda do cargo de magistrado vitalício, dentre as atribuições do Conselho Nacional de Justiça, essa é que poderia encher-se de vistosa inconstitucionalidade, perante 0 art. 95, inc. I, da Constituição da República, que restringe, taxativamente, as hipóteses em que pode dar-se a perda. Nada valeria tornar a submeter a locução suprimida ao escrutínio da Câmara dos Deputados, se eventual norma resultante da aprovação estaria fadada a ser tida por inconstitucional, como bem alvitrou o parecer da PGR:

“[...] a supressão da expressão 'perda do cargo' não comprometeu a aprovação do remanescente, vale dizer, do conteúdo temático do texto normativo, posto que [sic], reconheceu-o a própria inicial, a expressão até então existente era 'flagrantemente inconstitucional', por indispor-se até mesmo 
ante a literalidade do artigo 95, I parte final, da Constituição Federal, daí porque a supressão preserva o conjunto remanescente, para trilharmos o correto pensamento do Min. Octávio Gallotti" (fls. 194).

14. A autora formulou, ainda, aditamento à petição inicial, para acrescer fundamento à pretensão. Encontra-se pendente de apreciação, na Câmara dos Deputados, proposta de acréscimo de mais um parágrafo ao art. 103-B da Constituição, com o seguinte teor:

" $\$ 8^{\circ}$ É vedado ao membro do Conselho, referido nos incisos XII e XIII, durante o exercício do mandato:

a) exercer outro cargo ou função, salvo uma de magistério;

b) dedicar-se a atividade político-partidária;

c) exercer, em todo o território nacional, a advocacia."

Segundo a AMB, a falta de norma semelhante no corpo da Emenda Constitucional $n^{\circ}$ 45/2004 significaria que as vedaçōes propostas não se aplicariam aos advogados e cidadãos integrantes do Conselho Nacional de Justiça, daí resultando tratamento desigual entre seus membros, o que seria inconciliável com a Constituição da República (fls. 130-132).

O raciocínio da autora, mais uma vez, não conduz a declaração de inconstitucionalidade do Conselho Nacional de Justiça. A pendência da proposta voltada a incorporar aqueles impedimentos à ordem constitucional não implica que lhes não estejam sujeitos os advogados e cidadãos integrantes do Conselho. Basta juízo analógico baseado nos arts. 95 , parágrafo único, e $127, \$ 5^{\circ}$, inc. II, da Constituição Federal, para tirar-se a limpo que ninguém pode desempenhar atividades incompatíveis com a função de membro do Conselho, tais como as previstas naquele projeto e independentemente de sua conversão em regra constitucional específica. Da ausência desta não se infere inconstitucionalidade daquele, por insulto ao princípio isonômico.

15. Diante de todo o exposto, não conheço do pedido declaratório de inconstitucionalidade do art. $125, \mathbb{S} 8^{\circ}$, haja vista a inexistência de tal dispositivo no texto da Emenda Constitucional no 45/2004 afinal promulgado, e, em relação aos demais, julgo improcedente a ação. 